\title{
Tall Pinus luzmariae trees with genes from $P$. herrerae
}

\author{
Christian Wehenkel ${ }^{\text {Corresp., } 1}$, Samantha R Mariscal-Lucero ${ }^{1,2}$, M. Socorro González-Elizondo ${ }^{3}$, Víctor A Aguirre- \\ Galindo ${ }^{1}$, Matthias Fladung ${ }^{4}$, Carlos A López-Sánchez ${ }^{5}$ \\ ${ }^{1}$ Instituto de Silvicultura e Industria de la Madera, Universidad Juárez del Estado de Durango, Durango, Mexico \\ 2 Instituto Tecnológico Valle del Guadiana, Durango, Mexico \\ 3 CIIDIR Durango, Instituto Politécnico Nacional, Durango, Mexico \\ 4 Thünen-Institute of Forest Genetics, Grosshansdorf, Germany \\ 5 Escuela Politécnica de Mieres, Universidad de Oviedo, Mieres, Spain \\ Corresponding Author: Christian Wehenkel \\ Email address: wehenkel@ujed.mx
}

Context: Pinus herrerae and P. luzmariae are endemic to western Mexico, where they cover an area of more than 1 million hectares. Pinus herrerae is also cultivated in field trials in South Africa and South America, because of its considerable economic importance as a source of timber and resin. Seed quality, afforestation success and desirable traits may all be influenced by the presence of hybrid trees in seed stands. Aims: We aimed to determine the degree of hybridization between $P$. herrerae and $P$. luzmariae in seed stands of each species located in the Sierra Madre Occidental, Durango, Mexico. Methods: AFLP molecular markers from samples of 171 trees across five populations were analyzed with STRUCTURE and NewHybrids software to determine the degree of introgressive hybridization. Morphological analysis of 131 samples from two populations of $P$. herrerae and two populations of $P$. luzmariae was also conducted. The data were compared by Principal Coordinate Analysis (PCOA) in GenAlex 6.501. Results: Hybridization between Pinus herrerae and $P$. luzmariae was observed in all seed stands under study and resulted in enhancement of desirable silvicultural traits in the latter species. In P. Iuzmariae, all molecularly detected hybrids correspond to those identified on a morphological basis. However, the morphology of $P$. herrerae is not consistent with the molecularly identified hybrids from one population and is only consistent with $40 \%$ of those from the other population. Conclusions: This is the first report of hybrid vigour (heterosis) in Mexican pines. Information about hybridization and introgression is essential for developing effective future breeding programs, successful establishment of plantations and management of natural forest stands. Understanding how natural hybridization may influence the evolution and adaptation of pines to climate change is a cornerstone to sustainable forest management. 


\section{Tall Pinus luzmariae trees with genes from $P$. herrerae}

2 Christian Wehenkel ${ }^{1 *}$, Samantha del R. Mariscal-Lucero ${ }^{2}$, M. Socorro González-Elizondo ${ }^{3}$,

3 Víctor A. H. Aguirre-Galindo ${ }^{1}$, Matthias Fladung 4 , Carlos A. López-Sánchez ${ }^{5}$

41 Instituto de Silvicultura e Industria de la Madera, Universidad Juárez del Estado de Durango,

5 México. E-mail: wehenkel@ujed.mx, vaguirre@mex.tuv.com

62 Instituto Tecnológico Valle del Guadiana, Durango, México. E-mail: crocio@ujed.mx

73 CIIDIR Durango, Instituto Politécnico Nacional, México. E-mail: herbario_ciidir@ipn.mx

84 Thünen-Institute of Forest Genetics, Germany. E-mail: matthias.fladung@thuenen.de

95 Escuela Politécnica de Mieres, Universidad de Oviedo, Mieres, Spain. E-mail:

10 lopezscarlos@,uniovi.es

Key message: The occurrence of hybrids in seed stands may influence seed quality and afforestation success. Here, we provide the first report of hybrid vigour in seed stands of the Mexican tree species Pinus luzmariae $\times$ P. herrerae.

\section{Abstract}

Context: Pinus herrerae and P. luzmariae are endemic to western Mexico, where they cover an area of more than 1 million hectares. Pinus herrerae is also cultivated in field trials in South Africa and South America, because of its considerable economic importance as a source of timber and resin. Seed quality, afforestation success and desirable traits may all be influenced by the presence of hybrid trees in seed stands.

Aims: We aimed to determine the degree of hybridization between $P$. herrerae and $P$. luzmariae in seed stands of each species located in the Sierra Madre Occidental, Durango, Mexico.

Methods: AFLP molecular markers from samples of 171 trees across five populations were analyzed with STRUCTURE and NewHybrids software to determine the degree of introgressive hybridization. Morphological analysis of 131 samples from two populations of $P$. herrerae and two populations of $P$. luzmariae was also conducted. The data were compared by Principal Coordinate Analysis (PCoA) in GenAlex 6.501.

Results: Hybridization between Pinus herrerae and P. luzmariae was observed in all seed stands under study and resulted in enhancement of desirable silvicultural traits in the latter species. In $P$. luzmariae, all molecularly detected hybrids correspond to those identified on a morphological 
31 basis. However, the morphology of $P$. herrerae is not consistent with the molecularly identified hybrids from one population and is only consistent with $40 \%$ of those from the other population. Conclusions: This is the first report of hybrid vigour (heterosis) in Mexican pines. Information about hybridization and introgression is essential for developing effective future breeding programs, successful establishment of plantations and management of natural forest stands. Understanding how natural hybridization may influence the evolution and adaptation of pines to climate change is a cornerstone to sustainable forest management.

Key words: AFLP; tree breeding; STRUCTURE; Australes; interspecific hybrids; tree species; timber; wood; monitoring

\section{Introduction}

Hybridization represents an important evolutionary force that can introduce much more new genetic material than is created by mutation events (Anderson, 1949; Wright, 1964). It can also act as an additional, perhaps more abundant, source of adaptive genetic variation than mutation (Grant \& Grant 1994), by allowing gene flow and recombination (Abbott et al., 2013; Hipp, 2018). Furthermore, hybridization is one of the key sources of species formation and diversity, and many species may have originated by this route (Linder \& Risenberg, 2004; Blanckaert \& Bank, 2018), perhaps even as much as between $30 \%$ and $80 \%$ of all species (Wendel et al., 1991). On the other hand, increasing rates of hybridization may also lead to the extinction of unique populations or species because of unsuccessful reproductive efforts or introgression with a more common species (Rhymer \& Simberloff, 1996; Blanckaert \& Bank, 2018). In times of rapid ongoing climate change, hybridization may thus contribute to further extinctions, sometimes weakening reproductive isolation among species (Owens \& Samuk, 2019) as well as supporting the development of novel segregating genotypes that will speed up adaptation to changes in climate (Chunco, 2014; Menon et al., 2019). Knowledge of hybridization has therefore deep practical reasons. Besides the adaptation issues, the presence of hybrid trees in seed stands "contaminates" the species' gene pool and thus may influence seed quality and afforestation success (Arnold \& Hodges, 1995; Rieseberg \& Carney, 1998).

The process of hybridization incorporates alleles from one species into the gene pool of another (Harrison, 1993). Interactions between the environment and genetic structure can thus 
62 lead to segregation of a novel taxon from parental types. Depending on the degree of 63 differentiation, hybrid offspring of two or more plants of different taxa are sometimes identified

64 as species, subspecies or variants (Futuyma, 1998; Tovar-Sánchez \& Oyama, 2004).

Hybrids often display post-mating reproductive difficulties relative to their ancestors. These difficulties include hybrid weakness, sterility and fitness breakdown (Rieserberg \& Carney, 1998). However, hybrids are not necessarily uniformly unfit. On the contrary, some genotypic classes may be equally fit or even fitter than the parental taxa (Arnold \& Hodges, 1995; Mabaso et al., 2019). The first hybrid generation $\left(F_{1}\right)$ tends to exceed the parental generation in vegetative vigour or robustness, in a condition also known as heterosis. However, early hybrid generations such as $F_{2}$ and $F_{3}$ are often less vigorous and fertile than their parents due to the break-up of adaptive gene arrangements (Rieserberg \& Carney, 1998).

Studies involving hybridization are often based on morphological traits. However, the phenotypic expression of characters of one taxon in another does not necessarily indicate hybridization. Similar characters may occur in species because of phenotypic plasticity, convergent evolution or simply because of a common ancestry, as Linder et al. (1998) observed in wild sunflower. Furthermore, morphological characters yield limited information when the parents and their hybrids are affected by environmental factors such as disease or drought stress, generating a wide range of phenotypic variability. This problem is increased by subsequent backcrossing of the hybrids to either parent species, resulting in morphological characters that become more similar to those of the backcrossed parent species (Chen et al., 2004).

Use of molecular markers to detect interspecific hybridization is more effective than verification by morphological, chemical or cytogenetic analysis, especially as access is available to an almost unlimited number of molecular markers (Rieseberg et al., 1993; Alexandrov \& Karlov, 2018; Jasso-Martínez et al., 2018). Introgressive hybridization in many plant species has been identified by molecular data (Rieseberg et al., 1993; Arnold, 1997; Delgado et al. 2007; Kaplan \& Fehrer, 2007; McVay et al., 2017). These markers have been useful for diagnosing $F_{1}$ and derived hybrid generations, evaluating levels of gene flow among species and reconstructing phylogenetic relationships between hybridizing taxa and their close relatives (Rieseberg et al., 1993).

Amplified Fragment Length Polymorphism (AFLP) markers have been successfully used to detect introgressive hybridization in plants (Guo et al., 2005; Shasany et al., 2005; Koerber et 
93 al., 2013), specifically in pines (Xu et al. 2008; Stewart et al., 2010; Vasilyeva \& Semerikov, 94 2014; Ávila-Flores et al., 2016). AFLP markers include a more or less large number of

95

96 polymorphic, di-allelic loci and can be developed relatively easily and at a relatively low cost, even for species about which no prior genetic information is available (Mueller \& Wolfenbarger, 1999; Hardy et al., 2003; Paun \& Schönswetter, 2012). Possible disadvantages of the AFLP technique such as compiling standardized patterns in a database for interlaboratory use and future reference can be avoided by using specific procedures as recommended by Savelkoul et al. (1999). However, AFLP as dominant marker does not allow identification of homologous alleles and thus scoring of homozygote and heterozygote states (Mueller \& Wolfenbarger, 1999).

Interspecific hybridization is very common in natural stands of the genus Pinus (Critchfield, 1967; Quijada et al., 1997; Conkle \& Critchfield, 1988; López Upton et al., 2001; Delgado et al., 2007; Ávila-Flores et al., 2016; Stacy et al., 2017; Vasilyeva \& Goroshkevich, 2018; Mo et al., 2019), because of very weak reproductive barriers between pine species (Little \& Righter, 1965; Garrett, 1979; Dungey, 2001); this could be generalized across conifers with similar divergence history (Menon et al., 2018). Interspecific $F_{l}$ hybrids in this genus are highly viable and fertile (Critchfield 1975), which complicates taxonomic classification (Martínez, 1948; Lanner, 1974). Genetic diversity is often high in Pinus because of the usually large populations, cross-fertilization, high mutation rates and long-distance dispersion of pollen and sometimes seeds (Gernandt et al., 2011), as well as interspecific hybridization and introgression (Critchfield, 1967, 1975; Quijada et al., 1997; Conkle \& Critchfield, 1988; Ledig, 1998; LópezUpton et al., 2001; Ávila-Flores et al., 2016). In addition, understanding the phylogenetic relationships between closely related species of pines is also difficult due to retention of ancestral alleles (Delgado et al., 2007; Hernández-León et al., 2013; Ortiz-Martínez \& Gernandt, 2016). Moreover, North American hard pines in the subsection Australes share plastid DNA lineages due to introgressive hybridization or incomplete lineage sorting (Ortiz-Martínez \& Gernandt, 2016).

Pinus herrerae Martínez and Pinus luzmariae Pérez de la Rosa belong to the subsection Australes, a monophyletic group including 29 pine species (Gernandt et al., 2005; HernándezLeón et al., 2013). Herrera's pine (P. herrerae), also known as Pinus teocote var. herrerae (Martínez) Silba, is endemic to western Mexico, where it covers an area of about 1 million hectares (M ha) (Comisión Nacional Forestal, 2009) in mountain ranges between $16^{\circ}$ and $28^{\circ} \mathrm{N}$, 
124 at elevations ranging from 1,100 $\mathrm{m}$ to 2,800 $\mathrm{m}$ (Dvorak et al., 2007; Wehenkel et al., 2015). The 125 species is used to produce construction timber and resin (Martínez, 1948). It is also cultivated as 126 an exotic in field trials in South Africa and South America because of its typically very tall, 127 straight trunk (Dvorak et al., 2007). Pinus luzmariae (three-needled egg-cone pine), previously 128 known as Pinus oocarpa var. trifoliata Martínez, was first recognized as a separate species by 129 Pérez de la Rosa (1998). This small to medium-sized tree species is endemic to Mexico and it 130 has been reported as covering an area of about 200,000 ha (Comisión Nacional Forestal, 2009). 131 However, its distribution is not clear because it has been included in the very wide range of $P$. oocarpa Schiede ex Schltdl. The two largest populations are documented in the southern Sierra Madre Occidental covering about 1,000 hectares in south Durango and about 600 ha in northern Jalisco, respectively. Although no uses have been documented for Pinus luzmariae, it may be used as a source of timber, in the same way as P. oocarpa. The number of mature individuals of this species in its natural habitat is decreasing (Pérez de la Rosa \& Farjon, 2013).

Both pine species grow in the Madrean-tropical subregion of the Sierra Madre Occidental, at lower elevations $(<2,400 \mathrm{~m})$. Pinus herrerae often is dominating in subhumid areas whereas $P$. luzmariae occupies sites with poor soils, although sometimes they grow together (González-Elizondo et al., 2012c, González-Elizondo at al., 2013). The ecological niches of these two species are clearly defined by soil $\mathrm{pH}$ and climate in the State of Durango (Mexico) (Wehenkel et al., 2015).

Population genetics studies of $P$. herrerae are scarce (see Wehenkel et al., 2015) and of P. luzmariae non-existent. Hybrids between these two species have not yet been reported so far. The aim of the present study was therefore to use AFLP molecular markers and morphological traits to determine the degree of hybridization between $P$. herrerae and $P$. luzmariae in seed stands of each species located in the Sierra Madre Occidental mountain system, Durango, Mexico. Although P. herrerae and P. luzmariae are morphologically very different (Perry, 1991; Farjon \& Styles, 1997; García-Arévalo \& González-Elizondo, 2003; Pérez de la Rosa \& Vargas Amado, 2009), they are genetically closely related and can thus, theoretically, easily hybridize with each other (Dvorak et al., 2000; Ortiz-Martínez \& Gernandt, 2016; Gernandt et al., 2018). In addition, we tested the possible $P$. luzmariae hybrid individuals for clues of possible hybrid vigour (heterosis). We aimed to unravel introgressive hybridization between $P$. herrerae and $P$. luzmariae, under the assumption that effective pollen flow has occurred between the two species. 
Material and methods

157

158

159

160

161

162

163

164

165

166

167

168

169

170

171

172

173

174

175

176

177

178

179

180

181

182

183

184

185

\section{Study sites}

Samples were obtained from trees grown in three Pinus herrerae $(\mathrm{PH})$ and two $P$. luzmariae (PL) seed stands located in the Sierra Madre Occidental, state of Durango (NW Mexico) (collection permit SEMARNAT SGPA/DGVS/003644/18). The three $P$. herrerae seed stands were (1) Ranchito (PH-R), (2) Manchón del Abies (PH-A) and (3) Ventana (PH-V). The P. luzmariae stands were (4) Laguna (PL-L) and (5) Tacuache (PL-T). All seed stands are uneven-aged and located in natural populations (Table 1).

The three PH seed stands grow on slightly acidic soil $(\mathrm{pH} 5.2 \pm 0.4$ (standard deviation [SD]), with $\mathrm{H}^{+}$representing 27.4 $\pm 6.2 \mathrm{SD}$ of total exchangeable cations) (Wehenkel et al., 2015).

The Julian date of the last frost date in spring $\left(S_{\text {day }}\right)$ was 118 (equivalent to April 28) \pm 13 days SD. The elevation ranges between 2,318 and 2,511 $\mathrm{m}$ above sea level in the study area, with annual rainfall between 1,046 and 1,116 $\mathrm{mm}$. The mean temperature varies from about 11 to $13^{\circ} \mathrm{C}$. The PL stands are also situated on slightly acidic soils with $\mathrm{pH} 5.0 \pm 0.4 \mathrm{SD}$ and $\mathrm{H}^{+}$ representing $29.3 \pm 5.6 \% \mathrm{SD}$ of total exchangeable cations, although at lower elevations with an earlier $S_{d a y}$ and higher temperatures. Their elevation varies from 1,960 to 2,140 $\mathrm{m}$ above sea level, $S_{\text {day }}$ is 77 (equivalent to March $18 \pm 13$ days SD, with annual rainfall of between 1,107 and $1,139 \mathrm{~mm}$. The mean temperature ranges between 14 and $16^{\circ} \mathrm{C}$.

The PH-R and PH-A stands are separated from PL-L and PL-T by a deep $(1,400 \mathrm{~m})$ canyon and by a distance of 8.1-11 km (Fig. 1). The three PH stands include typical specimens of $P$. herrerae, i.e. tall trees, of height up to $40 \mathrm{~m}$. However, both populations of $P$. luzmariae under study showed uncommon increased fitness relative to other populations of the same species (e.g. Pérez de la Rosa, 1998; García-Arévalo \& González-Elizondo, 2003), as they are taller (see more in Discussion).

\section{Fluorescence-based semi-automated AFLP analysis}

Needles were collected from a total of 171 adult, dominant and superior putative phenotypes, i.e. plus trees, according to previously described selection criteria (Wehenkel et al., 2015), of both $P$. herrerae and $P$. luzmariae (33-35 per stand). Dendrometric variables were also 
186 recorded in all seed stands, including coordinates, height $(H)$ and diameter at breast height

$187(D B H)$ of each sampled tree. The samples were placed in individual tubes with a few drops of 188 ethanol and stored at $-10^{\circ} \mathrm{C}$ until DNA extraction.

189 DNA was extracted using the QIAGEN DNeasy96 plant kit, according to the steps 190 described in the product manual. DNA fingerprints were obtained by amplified fragment length 191 polymorphism (AFLP), according to a modification of the protocol of Vos et al. (1995), outlined 192 by Ávila-Flores et al. (2016). The restriction enzymes used were EcoRI (selective primer: 5'193 GACTGCGTACCAATTCNNN-3') and MseI (selective primer: 5'194 GATGAGTCCTGAGTAANNN-3'). The primer combination E01/M03 (EcoRI-A/MseI-G) was 195 used in the pre-AFLP amplification.

196 Selective amplification was carried out with the fluorescent-labelled (FAM) primer pair 197 E35 (EcoRI-ACA-3) and M63+C (MseI-GAAC). All PCR reactions were carried out in a Peltier 198 Thermal Cycler (MJ Research, Waltham, Massachusetts, USA). The amplified restriction 199 products were electrophoretically separated in a Genetic Analyzer (ABI 310016 capillaries), 200 with a GeneScan 500 ROX internal size standard (Applied Biosystems, Foster City, California, 201 USA). The size of the AFLP fragments was resolved with the GeneScan ${ }^{\circledR} 3.7$ and Genotyper ${ }^{\circledR}$ 3.7 software packages (Applied Biosystems, Foster City, California, USA).

The amplified restriction products were scored automatically. Only high quality 204 fragments above the signal threshold of 50 (minimum peak height) (according to ABI manual) 205 and with a maximum peak width of 1.0, minimum fragment size of 75 base pairs (bp), maximum fragment size of $450 \mathrm{bp}$ and tolerance $+/-$ bp of 0.4 were considered. Two fragments were only considered when the peak-peak distance between the two signals was at least $0.5 \mathrm{bp}$. The quality and reproducibility of the analysis were verified by inclusion of reference samples in each plate and independent repetition (replicate PCRs) of analysis at least 16 samples (i.e. a minimum of 16 randomly chosen individuals from each plate). In all replicates, the AFLP pattern was the same as in the first analysis (Simental-Rodríguez et al., 2014; Ávila-Flores et al., 2016).

Two binary AFLP matrices were generated from the presence (code 1) or absence (code 0 ) at probable band positions (Table S1). The bands detected represented the presence of a dominant genetic variant (plus phenotype) with unknown mode of inheritance of this band position (detected fragment length) (Vuylsteke et al., 1999; Kraus, 2000). The absence of a band indicated the presence of only recessive genetic (allelic) variants at the given position (locus). To 
217 minimize the rate of size homoplasy (Vekemans \& Hardy, 2004; Caballero et al., 2008) and 218 technical artefacts (Kraus, 2000), only the polymorphic loci (fragment lengths) with frequencies 219 of occurrence of between 5 and 95\% were selected for study (SanCristobal et al., 2006).

220

221

222

223

224

225

226

227

228

229

230

231

232

233

234

235

236

237

238

239

240

241

242

243

244

245

246

247

\section{Defining pure individuals and molecular identification of hybrids}

The trees PH-V4, PH-V49, PH-V52, PH-V64 and PH-V127, and PL-T28, PL-T31, PLT37, PL-T103, PL-T130 were defined as individuals of "pure" Pinus herrerae (PH) and $P$. luzmariae (PL), respectively, (hereinafter called pure individuals or pure trees) identified by their genetic affiliation probability and by their morphological traits (see details below).

When PH or PL stands include common hybrid trees, they should possess a genome that is a combination of alleles derived from trees belonging to both species. These hybrids can be detected by genetic data obtained from molecular marker analysis (Xu et al., 2008; Ávila-Flores et al., 2016).

The resulting AFLP loci from the 171 tree samples were used to determine the degree of introgressive hybridization between PH and PL in the analysis, conducted with STRUCTURE version 2.1 (Pritchard et al., 2000; Falush et al., 2007) and NewHybrids version 1.1 Beta 3 software (Anderson \& Thompson, 2002). Both software programs have been used to identify putative hybrids in Pinus with dominant markers such as AFLP (Xu et al., 2008; Ávila-Flores et al., 2016). The systematic Bayesian clustering approach applying Markov Chain Monte Carlo (MCMC) estimation, as implemented in STRUCTURE was used to test the affiliation of individuals to each species. The MCMC process started by randomly assigning individuals to a pre-determined population (group or species) number $(K)$ (here $K=2$, Fig. 2). Repeated many times in the burn-in process (burn-in period of 10,000 cycles), comprising 100,000 iterations, variant (allele) frequencies were estimated in each population and individuals re-assigned using those frequency estimates. In the course of the process, the convergence progressed toward reliable membership probabilities of individuals to a population (or species) (Porras-Hurtado et al., 2013).

If the probability of $\mathrm{PH}$ (or PL) affiliation of a putative PH (or PL) tree was less than 95\% according to STRUCTURE, then this individual was recorded as a candidate hybrid. The affiliation probability was measured by the proportion of the dominant STRUCTURE populations in the studied stands (Table S2). Individuals were identified as first-generation $\left(F_{l}\right)$ 
248 hybrids when the probability of PH affiliation with a PL tree was in the range 48-52\% (Xu et al., 249 2008; Ávila-Flores et al., 2016).

250 Use of the Markov chain Monte Carlo (MCMC) methodology and 100,000 sweeps after 251 BurnIn (10,000 cycles), the NewHybrids 1.1 software (Anderson \& Thompson, 2002) is suitable 252 for the situation studied here, where only two diploid species appear to be hybridizing. By 253 applying this software, Anderson (2008) showed that just ten AFLP were adequate to accurately 254 separate parental and $F_{1}$ genotypes from later generation hybrid classes. A sample of $M$ 255 individuals, putative pure individuals as well as hybrid individuals, is obtained and genotyped at 256 the $L$ loci of codominant and dominant genetic markers. This software contemplates six genotype 257 classifications (pure species 1 , pure species $2, F_{1}$ hybrids, $F_{2}$ hybrids, and the first backcross 258 generation to pure species 1 or pure species 2) and estimates the probability that each individual 259 belongs to the different classes (Anderson \& Thompson, 2002; Anderson, 2008; Xu et al., 2008) 260 (Table S3). A tree was assigned to one of the hybrid classes with a posterior probability of at 261 least $95 \%$.

To visualize individual and species differences, Principal Coordinate Analysis (PCoA) was also performed using the binary AFLP data matrix produced, Nei`s Genetic Distance (Nei. 1972, 1978) and GenAlex 6.501 software (Peakall \& Smouse, 2012). The PCoA diagrams were elaborated with the first, second and third coordinate. cycles, 100,000 iterations) in detecting hybrids was quantified using the computer program Hybridlab 1.0 (Nielsen et al., 2006). However, this software simulates intraspecific hybrids from population samples of co-dominant nuclear genetic markers, whereas the AFLP-technique can detect only dominant genetic markers. Here, the accuracy corresponds with the number of correctly identified individuals for a hybrid generation over the actual number of individuals assigned to that generation (Marie et al., 2011).

Assuming that the fixed band differences between PH and PL were homozygous 274 (expected for fixed polymorphisms), a subset of 11 diagnostic AFLP loci of the five pure PH and PL trees distinguishing the two parental species (100\% of one reference parental species had the hybrid generations $\left(F_{1}(N=50)\right.$ and $F_{2}, F_{1} \mathrm{PL}, F_{1} \mathrm{PH}, F_{2} \mathrm{PL}, F_{2} \mathrm{PH}, F_{1} \mathrm{PL}-\mathrm{PL}$ and $F_{1} \mathrm{PH}-\mathrm{PH}$ 
279 differences between PH and PL. Consequently, it was not possible to reliably identify the

280 heterozygote or homozygote state by means of the AFLP bands, as found also by LaRue et al.

281 (2013). Nevertheless, these three simulated intraspecific hybrid generations were also created

282 when using all polymorphic AFLP loci assuming that the AFLP band was always the dominant

283 homozygote and the recessive variant the recessive homozygote. Finally, we performed

284 STRUCTURE and NewHybrids analyses to estimate their accuracy using the two simulation 285 datasets.

286

287 Morphological detection of hybrids

288 To test the results of the AFLP analysis, morphological analysis was conducted on 289 samples from the same trees in populations PH-A, PH-V, PL-L and PL-T sampled for the AFLP 290 analysis. At least 31 individual trees were analysed for cone traits and 11 for needle traits per 291 species. Samples of branchlets, needles and cones were collected for taxonomic determination 292 and morphometric examination, and voucher specimens were deposited in the CIIDIR herbarium 293 (acronym according to Thiers, 2019), the collection of the Centro Interdisciplinario de 294 Investigación para el Desarrollo Integral Regional of the Instituto Politécnico Nacional (Tables 295 S4 and S5). Morphological characters were selected from those used by Martínez (1948) and 296 Pérez de la Rosa (1998) in their descriptions of $P$. herrerae and P. luzmariae, respectively, as 297 well as those used by García-Arévalo \& González-Elizondo (2003) to distinguish these two 298 species in the study area, considering sheath, needle and cone characters (Table 2, Tables S6 and 299 S7, Fig. S1). Characters that do not possess discrete or different states between $P$. herrerae and 300

301

302

303

304

305

306

307

308

309

$P$. luzmariae according to these authors were excluded from the analysis as they have no informative value for this study, e.g. number of leaves per fascicle (3 in both species), persistence of fascicle sheaths (persistent in both), and cone peduncle (peduncle present, oblique and about the same diameter in both species). Some of the characters were measured at $\mathrm{x} 40$ with the aid of a Carl Zeiss Dicovery.V8 stereo microscope. Individual and species differences were pictured by PCoA.

In order to detect PH and PL hybrids identified by morphological traits, we first identified five pure PH (PH-V 4, 49, 52, 64, 127) and five pure PL (PL-T 28, 31, 37, 103, 130) trees, applying a genetic affiliation probability larger than 0.99 according to STRUCTURE and NewHybids and clearly assignable by morphological traits. Since not every independent 
310 morphological trait was normally distributed and continuous, the species assignation of each tree

311 and "morphological" hybrids was established by Random Forest (Breiman, 2001) using the caret 312 package and function "train" (Kuhn, 2008; Williams et al., 2018) available in the free statistical 313 application R 3.5.2 (R Development Core Team, 2018). For this purpose, the PH trees were 314 labeled with the value " 1 " (corresponding to the presence of PH) and the PL trees were labelled 315 with " 0 " (corresponding to the absence of $\mathrm{PH}$ ) in this presence-absence classification model. 316 The model for both the cone traits and needle traits, respectively, was fit using a 5-fold cross317 validation repeated 10 times (i.e., using $80 \%$ of the dataset as training set and the remaining $20 \%$ 318 as testing set). Random Forest is a nonparametric tree-based classifier and hence does not require 319 variable scaling and can successfully handle non-normality (Strobl, Malley \& Tutz, 2009) as 320 well as categorical and confounding variables (Dormann et al., 2013). Caret package (short for 321 Classification And REgression Training) is a complete framework for building machine learning 322 models (http://caret.r-forge.r-project.org).

323 Using all morphological traits listed in Table 2, a tree was classified as a possible PH (or PL) 324 tree if it was assigned to each of those species with the highest assignment probability (i.e., > $32550 \%$ ). If the posterior probability of PH (or PL) affiliation of a possible PH (or PL) tree was less 326 than $95 \%$ according to Random Forest, then, that tree was considered as a putative PH (or PL) 327 hybrid.

328 The predictive ability of the Random Forest model was evaluated using the True Skill Statistic 329 (TSS; Allouche, Tsoar \& Kadmon, 2006) using the caret package in $R$ (for more details see 330 Escobar-Flores et al., 2018). TSS (also known as the Hanssen-Kuipers discriminant) is an 331 appropriate alternative to Area Under a Receiver Operating Characteristic (ROC) Curve (AUC; 332 Fawcett, 2006) in cases where model predictions are formulated as presence-absence models and 333 an improvement to the widely used kappa. TSS not only accounts for both omission and 334 commission errors, but is not affected by the sample size of each class. The TSS is defined as 335 sensitivity + specificity -1 , and ranges from -1 to +1 , where +1 indicates a perfect classification 336 model and values of zero or less indicate performance no better than random (Allouche, Tsoar \& 337 Kadmon, 2006; Tatler, Cassey \& Prowse, 2018).

Results

\section{Molecular detection of hybrids}


The AFLP primer combination yielded 348 polymorphic bands of 75-450 base pairs

342 across all individual specimens of Pinus herrerae (PH) and Pinus luzmariae (PL). PH yielded 343338 and PL 316 polymorphic bands. Both species shared 304 AFLP fragments (87.4\% of 344 polymorphic bands detected).

345 Fig. 2 shows the percentage of hybridization obtained with the STRUCTURE software, 346 for $K=2$, the three PH seed stands have a dominant genetic variant (blue) and the two PL seed 347 stands contain another dominant genetic variant (red). Based on a 5\% probability of introgression 348 of gene content, 92 (53.8\%) putative hybrids between PH and PL were found in all the seed 349 stands analysed. Thus, $18 \%$ of the individuals in the Ranchito $\mathrm{PH}$ stand (PH-R) were putative 350 hybrids; all PH individuals in the Manchón del Abies PH stand (PH-A) displayed genetic 351 introgression from PL, and 14 of the 35 individuals in the Ventana PH stand (PH-V) were 352 putative hybrids (40.0\%). Regarding P. luzmariae, 30 (85.7\%) putative hybrids were detected in 353 the Laguna stand (PL-L), whereas seven individuals (21.2\%) in the Tacuache P. luzmariae stand 354 (PL-T) displayed introgression with $P$. herrerae. Five trees were first-generation hybrids $\left(F_{1}\right)$, as 355 356 indicated by introgression of between 45 and 55\%: three trees in the PH-A stand and another two in the PL-L stand (Fig. 2, Table 3).

NewHybrids software clearly identified 65 (38\%) putative hybrids between PH and PL (Table 3). No putative hybrids were found in the Ranchito PH stand (PH-R). In total, 25.7\% of the individuals in the PH-A were putative hybrids, and two of the 35 individuals in the Ventana $\mathrm{PH}$ stand (PH-V) were putative hybrids (5.7\%). A large majority $(94.2 \%)$ of the individuals in the Laguna P. luzmariae stand (PL-L) were identified as putative hybrids, whereas $64 \%$ of the 362 individuals in the Tacuache $P$. luzmariae seed stand (PL-T) displayed genetic introgression with $P$. herrerae. Only one tree, located in the PL-L stand, was detected as a first-generation hybrid $\left(F_{1}\right)$ (Table 3).

The accuracy test showed that the method NewHybrids (NH) correctly assigned at least 88\% of naturally occurring "pure" PH and PL individuals using 11 diagnostic AFLP and all 348 AFLP. STRUCTURE (STR) presented much more errors, especially with the 11 diagnostic AFLP. Using the 11 diagnostic loci, for both methods detections of $1^{\text {st }}$ and $2^{\text {nd }}\left(F_{2}, F_{1} P L\right.$ and $F_{1} P H$ backcrosses) generation hybrids were $100 \%$ and nearly $100 \%$, for $3^{\text {rd }}$ generation hybrids $\left(F_{2} \mathrm{PL}, F_{2} \mathrm{PH}, F_{1} \mathrm{PL}-\mathrm{PL}\right.$ and $F_{1} \mathrm{PH}-\mathrm{PH}$ backcrosses) this decreased further to $0.59 \%$ in $\mathrm{STR}$ and 371 $0.49 \%$ in NH (posterior probability (PP) of at least 95\%). Using the all 348 AFLP, simulations 
372 demonstrated lower rates of inaccurately than the test with 11 diagnostic loci. STR and NH

373 correctly assigned $100 \%$ of simulated $F_{1}$ hybrids and nearly $100 \%$ of $2^{\text {nd }}$ generation hybrids.

374 Moreover, NH correctly assigned $100 \%$ of simulated $3^{\text {rd }}$ generation hybrids, too. Using STR, a

375 lower percentage of $3^{\text {rd }}$ generation hybrids were correctly assigned (50\%) (PP of at least 95\%)

376 (Table 4).

377 The results of the Principal Coordinates Analysis (PCoA) comparing genetic differences

378 between individual specimens of PH and PL are shown in Fig. S2. At the individual level, the

379 first three coordinates in PCoA explained $13.4 \%$ of the variability.

380

381

\section{Morphological detection of hybrids}

382 Pinus herrerae and $P$. luzmariae are morphologically distinct and easily recognized by several needle traits as well as by the width, scale position and scale length of the cone. However, various morphological intermediates between the two species were found (Fig. 3 and 4),

including hybrids confirmed by Random Forest (Table 5, Fig. 5) considering seven cone (hybrid proportion of 4.6\%) and eight needle traits (4.5\%). Every observation was correctly classified $(\mathrm{TSS}=+1)$. At the individual level, the first three coordinates in PCoA only explained $36.2 \%$ of the variability in seven cone traits, but $61.7 \%$ of the variability in eight needle traits (Fig. S3 and S4). Hybrids identified by 15 morphological traits matched only $13.4 \%$ of the molecularly detected hybrids, and $5.7 \%$ of hybrids were only found by morphological traits.

\section{Clues of possible hybrid vigour (heterosis) in P. luzmariae}

393

In this study of 69 P. luzmariae (pure and hybrid) trees, the hybrid heights and DBHs were much heterogeneously distributed than the dimensions of the pure trees. The smallest (one tree with 14 $\mathrm{m}$ height) and the tallest trees (14 trees with $23-30 \mathrm{~m}$ ) were hybrids. The pure trees presented a normal distribution (probability) in which the expected proportion of trees higher than $24 \mathrm{~m}$ was much lower than the observed frequency of the tallest hybrids (Fig. 6).

Discussion

401

Species crossability in pines is of great theoretical and practical interest (Lopez et al., 2018; Vasilyeva \& Goroshkevich, 2018). Many pine hybrids, including several Mexican species, 
403 have been planted in trials across southern Africa in different conditions and climate regimes 404 (Hongwane et al., 2018). Here, we report for the first time about the occurrence of hybrids in 405 Pinus luzmariae, a little known species, introgressed by $P$. herrerae, revealing taller trees in 406 comparison to all populations previously known for the species (as compared with those 407 described in Pérez de la Rosa (1998) and García-Arévalo \& González-Elizondo (2003)). 408 Populations of the introgressed $P$. luzmariae include trees 14 to $30 \mathrm{~m}$ (vs. 6-12 m in most other 409 populations) (Fig. 6). This can be interpreted as hybrid vigour or heterosis, being the first report 410 for Mexican pines. Other studies have shown that hybrid pines in the country do not differ from 411 the pure trees in relation to vigour or robustness, e.g. Pinus oocarpa $\times$ P. pringei (López-Upton 412 et al., 2001) and P. arizonica $\times$ P. engelmannii (Ávila-Flores et al., 2016). In comparison with 413 other populations of the same species, populations of the introgressed P. luzmariae (PL) display 414 some important characters that are used to select superior forest trees (Kedharnath, 1984), i.e. 415 good growth vigour, superior height, good self-pruning, and straight cylindrical bole. In the two 416 introgressed populations, $P$. luzmariae formed almost pure, relatively dense stands with a few 417 specimens of $P$. herrerae $(\mathrm{PH})$ and Pinus devoniana in association, in contrast to the open, 418 mixed stands in which $P$. luzmariae usually grows.

419 The high percentage of AFLP fragments (87\%) shared by P. herrerae and P. luzmariae 420 resulted in a large proportion of putative hybrids (54\% by STRUCTURE (STR) and $38 \%$ by 421 NewHybrids (NH)) using a posterior probability of at least 95\%. The accuracy test detecting the 422 different hybrid classes showed comparable results to other studies. However, NH detected more 423 of both, accurate hybrids and individuals of pure species, than STR (Table 4). This explains the 424 notable difference in the putative hybrid number found between STR (92 hybrids) and NH (65 hybrids). Therefore, the results presented by NH are probably more precise.

Previous studies have reported that the accuracy of these software can differ greatly depending on the population context (Vähä and Primmer 2006). Using AFLP and a PP of at least 90\%, LaRue et al. (2013) presented $100 \%$ accuracy rate of simulated $F_{1}$ hybrids, but lower percentages of $F_{2}$ and backcrosses (about $91 \%$ and 92\%, respectively). Cullingham et al. (2011) found a mean power of $74 \%$ to detect hybrids using microsatellites and a PP of at least $90 \%$ for $F_{1}$ hybrids and $\mathrm{PP}<90 \%$ for other hybrid classes.

The high degree of introgression can be explained by the relatively recent diversification 433 of species in the subsection Australes and the very weak reproductive barriers between them 
434 (Little \& Righter, 1965; Garrett et al., 1979; Dvorak et al., 2000; Vargas-Mendoza et al., 2011;

435 Gernandt et al., 2018). Similar weak reproductive barriers and high recent speciation rates have 436 been recorded for madrones (Arbutus spp.) and oaks (Quercus spp.) (González-Elizondo et al., 437 2012a, 2012b, 2013; Hipp et al., 2019), the other two tree genera that, along with pines, 438 dominate in the temperate forests of the Sierra Madre Occidental in western Mexico, where this 439 study was carried out. Introgressive hybridization, although usually not obvious, may be more 440 important in evolution than those cases in which hybridization is evident (Anderson, 1949; Hipp 441 et al., 2019).

442 The interspecific gene transfer between the two pine species studied here is also 443 supported by (i) wind pollination, (ii) longevity of individual trees, (iii) overlapping generations, 444 (v) large effective population sizes, and (vi) weak physical barriers caused by sympatric 445 distribution (Ávila-Flores et al., 2016). The relatively high diversity and high levels of gene flow 446 in trees (relative to herbs and shrubs) is favoured by their outcrossed mating system and long 447 distance seed dispersal (Petit \& Hampe, 2006).

448 Of the five seed stands studied, PL-L displayed the highest degree of hybridization 449 (94\%), confirmed by AFLP as well as cone and needle traits (Tables 3 and 4). According to the 450 PCoA results (Fig. S2, S3 and S4), many PL-L individuals were genetically closely related to $P$. 451 herrerae individuals. The high phenotypic plasticity and more luxuriant growth found in both 452 populations of $P$. luzmariae under study (Table 3 and 5) are a consequence of the hybrid origin. 453 Crossbreeding or heterozygosity promotes variability, as found by Strauss (1987) for 454 heterozygous trees of Pinus attenuata Lemm. derived from crossbreds. Resistance to disease, 455 pathogens or environmental stresses has been a target in tree breeding towards interspecific 456 hybrids. For example, Pinus patula Schltdl. \& Cham. has been crossed with P. tecunumanii 457 F.Schwerdtf. ex Eguiluz et J.P.Perry and with P. oocarpa in plantations in South Africa to 458 increase tolerance to a fungal pathogen. The resulting hybrids of these three Mexican pines have 459 a low frost tolerance, so new crosses were made until the finding that $P$. patula $\times$ P. tecunumanii 460 from high elevations has a higher frost tolerance than P. patula $\times$ P. tecunumanii from lower 461 elevations (Mabaso et al., 2019).

462 The high degrees of hybridization have several possible consequences: (i) extinction of 463 one of the PH or PL parental species due to wasted mating effort or genetic swamping; (ii) 464 reinforcement of species boundaries; (iii) creation of a third, hybrid species; (iv) formation of a 
465 stable hybrid zone; and (v) partial introgression between the two hybridizing lineages (Chunco, 466 2014).

467

468

469

470

471

472

473

474

475

476

477

478

479

480

481

482

483

484

485

486

487

488

489

490

491

492

493

494

495

The stands of $P$. luzmariae we studied appear to represent a stable hybrid zone, like the Pinus engelmannii stand reported by Ávila-Flores et al. (2016). This conclusion is supported by the fact that the $P$. luzmariae population displays higher fitness than other populations of the species. Hybrid speciation does not occur in the studied populations as the hybrids are not spatially or ecologically isolated from the parental species, and no novel variants of morphological traits were found (Ungerer et al., 1998). The PH-A displayed the highest degree of hybridization in three PH studied (at least $37.1 \%$ consisting of at least $25.4 \%$ trees detected by NewHybrids and four extra trees detected by the cone and needle traits) (Tables 3 and 5). PH-A was located next to the two P. luzmariae seed stands (PL-L and PL-T), and it is expected that it intercepts large amounts of $P$. luzmariae pollen. We can, therefore, conclude that gene flow has occurred in both directions, from PL to PH and vice versa. However, gene flow from PH to PL seems to be more effective as more hybrids were found in the PL stands, both of which are located at lower elevations than the PH stands (Table 1).

Despite the large number of hybrids detected in the studied stands, the frequency of firstgeneration $\left(F_{1}\right)$ hybrids and backcrossing was low (Table 3), indicating that hybrid crossing was usual in the seed stands. Similar results have recently been reported in species of Salix and for pines in the subsection Ponderosae and (Fogelqvist et al., 2015; Ávila-Flores et al., 2016).

Natural hybridization has also been observed in other Mexican pine species (Gernandt et al., 2018). Previous studies of the subsection Australes identified natural hybridization between P. oocarpa $\times$ Pinus caribaea and P. oocarpa $\times$ Pinus pringlei only by morphological traits (Styles et al., 1982; López-Upton et al., 2001). In a study of Mexican pine species of the subsection Ponderosae, Ávila-Flores et al. (2016) observed a high degree of introgressive hybridization between P. engelmannii, Pinus arizonica, Pinus cooperi and Pinus durangensis. AFLP markers detected most of the putative hybrids (58\%), and only a few were detected by morphological features (15\%). Hybridization was not detected by morphological traits in $74 \%$ of all hybrids detected by AFLP. Hybrids and backcrossing were also found in Mexican Arbutus species that are common in disturbed areas (González-Elizondo et al., 2012a; González-Elizondo et al., 2012b). Natural pairwise and triple hybrids have also been detected in numerous Mexican Quercus stands (e.g. Peñaloza-Ramírez et al., 2010; Hipp et al., 2019). Natural hybridization 
496 between different Populus species and gene flow between cultivated poplars and native poplar 497 populations have been described for European riparian forests and stands (e.g. vanden Broeck et

498

499

500

501

502

503

504

505

506

507

508

509

510

511

512

513

514

515

516

517

518

519

520

521

522

523

524

525 al., 2004; Smulders et al., 2008; Lexer et al., 2005).

\section{Conclusions}

Hybridization between Pinus herrerae and P. luzmariae in seed stands in the Sierra Madre Occidental of Mexico has occurred in both directions to different degrees. Estimates of the success of hybrid individuals may be biased in this study by the fact that sampling was conducted in seed stands (in which plus trees predominate). Further research is necessary to increase our understanding of how hybridization may influence silvicultural traits in Mexican pines, as well as their evolution and adaptation to climate change. The successful survival and reproduction of these hybrids over generations will depend on their attributes, their fitness and the environmental factors influencing them (Strauss, 1987), given that hybridization leads to individuals which widely vary depending of the context, location and involved species (Gompert and Buerkle, 2016).

We conclude that both morphological and molecular approaches are essential to confirm the genetic identity of forest reproductive material as PH and PL frequently hybridize in all seed stands under study. Such information is very important for developing effective future breeding programs and successful establishment of plantations (Ávila-Flores et al., 2016) as well as for improving planning of the management of natural stands.

Introgressive hybridization in seed stands of Pinus herrerae and Pinus luzmariae generated outstanding plus trees. Because of their tall, straight trunks, hybrids of the largely unknown Pinus luzmariae represent a promising, valuable source of timber for wood industries as well as for reforestation in poor sites. The hybrid trees may be able to be cultivated after evaluation germplasm and vegetative propagation potential and may be suitable for commercial exploitation. However, further research is needed to examine the performance of hybrids and to assess their fertility and growth relative to those of pure species. Finally, monitoring natural hybridization is important in relation to sustainable forest management in Mexico.

\section{Acknowledgements}


526 We thank Sergio Simental-Rodriguez, Saskia Friedrich and Javier Hernández-Velazco for

527 assistance with fieldwork and dataset preparation and Imelda Flores for assistance with the

528 morphometric study.

529

\section{References}

531 Abbott R, Albach D, Ansell S, Arntzen JW, Baird SJE, Bierne N, Boughman J, Brelsford A, 532 Buerkle CA, Buggs R, Butlin RK, Dieckmann U, Eroukhmanoff F, Grill A, Cahan SH, 533 Hermansen JS, Hewitt G, Hudson AG, Jiggins C, Jones J, Keller B, Marczewski T, Mallet J, 534 Martinez-Rodriguez P, Möst M, Mullen S, Nichols R, Nolte AW, Parisod C, Pfennig K, Rice 535 AM, Ritchie MG, Seifert B, Smadja CM, Stelkens R, Szymura JM, Väinölä R, Wolf JBW, 536 Zinner D. 2013. Hybridization and speciation. J Evol Biol 26: 229-246. DOI: 10.1111/j.1420537 9101.2012.02599.x

538 Alexandrov OS, Karlov GI. 2018. Development of 5S rDNA-based molecular markers for the 539 identification of Populus deltoides Bartr. ex Marshall, Populus nigra L., and their hybrids. 540 Forests 9:604 DOI: 10.3390/f9100604.

541 Allouche O, Tsoar A, Kadmon R. 2006. Assessing the accuracy of species distribution models:

542 prevalence, kappa and the true skill statistic (TSS). Journal of Applied Ecology 43(6):1223-1232.

543 Anderson E. 1949. Introgressive hybridization. Wiley. New York, USA.

544 Anderson EC, Thompson EA. 2002. A model-based method for identifying species hybrids using 545 multilocus genetic data. Genetics 160:1217-1229.

546 Anderson EC. 2008. Bayesian inference of species hybrids using multilocus dominant genetic 547 markers. Philos Trans R Soc Lond B: B Sci 363(1505):2841-2850.

548 Arnold ML. 1997. Natural hybridization and evolution. Oxford University Press.

549 Arnold ML, Hodges SA. 1995. Are natural hybrids fit or unfit relative to their parents? Trends 550 Ecol Evol 10:67-71.

551 Ávila-Flores IJ, Hernández-Díaz JC, González-Elizondo MS, Prieto-Ruíz JÁ, Wehenkel C. 2016.

552 Degree of Hybridization in Seed Stands of Pinus engelmannii Carr. In the Sierra Madre 553 Occidental, Durango, Mexico. PloS ONE 11(4):e0152651 DOI:10.1371/journal.pone.0152651.

554 Blanckaert A, Bank C. 2018. In search of the Goldilocks zone for hybrid speciation. PLoS Genet 555 14(9):e1007613 DOI: 10.1371/journal.pgen.1007613. 
556 Bodenhofer U, Kothmeier A, Hochreiter S. 2011. APCluster: an R package for affinity 557 propagation clustering. Bioinformatics 27:2463-2464.

558 Breiman L. 2001. Random forests. Machine Learn. 45:5-32.

559 Caballero A, Quesada H, Rolán-Alvarez E. 2008. Impact of amplified fragment length 560 polymorphism size homoplasy on the estimation of population genetic diversity and the detection 561 of selective loci. Genetics 179:539-554.

562 Chen J, Tauer CG, Bai B, Huang Y, Payton ME, Holley AG. 2004. Bidirectional introgression 563 between Pinus taeda and Pinus echinata: evidence from morphological and molecular data. Can 564 J For Res 34:2508-2516.

565 Chunco AJ. 2014. Hybridization in a warmer world. Ecol Evol 4:2019-2031.

566 Comisión Nacional Forestal. 2009. Inventario Nacional Forestal y de Suelos de México 2004-

567 2009. Comisión Nacional Forestal, Zapopan, Jalisco, México.

568 Conkle MT, Critchfield WB. 1988. Genetic variation and hybridization of ponderosa pine. In:

569 Ponderosa Pine: the species and its management, Washington State University Cooperative 570 Extension, pp 27-43.

571 Critchfield WB. 1967. Crossability and relationships of the closed-cone pines. Silvae Genet 572 16:89-97.

573 Critchfield WB. 1975. Interspecific hybridization in Pinus: a summary review, pp. 99-105 in: DP 574 Fowler and CY Yeatman (eds.) Symp. on Interspecific and Interprovenance Hybridization in 575 Forest Trees. Proc. 14th Meeting, Canad. Tree Improv. Assoc., Part II.

576 Debreczy Z, Rácz I. 2011. Conifers around the World. Vols. 1-2. DendroPress Ltd., Budapest. 5771089 pp.

578 Cullingham CI, Cooke JE, Dang S, Davis CS, Cooke BJ, Coltman DW. 2011. Mountain pine 579 beetle host-range expansion threatens the boreal forest. Mol Ecol 20(10):2157-2171.

580 Delgado P, Salas-Lizana R, Vázquez-Lobo A, Wegier A, Anzidei M, Alvarez-Buylla ER, Piñero 581 D. 2007. Introgressive hybridization in Pinus montezumae Lamb and Pinus pseudostrobus Lindl. 582 (Pinaceae): morphological and molecular (cpSSR) evidence. Int J Plant Sci 168:861-875.

583 Development Core Team. 2014. R: A language and environment for statistical computing. R 584 Foundation for Statistical Computing, Vienna, Austria. Available: URL http://www.R585 project.org/. 
586 Dormann CF, Elith J, Bacher S, Buchmann C, Carl G, Carré G, et al. 2013. Collinearity: A 587 review of methods to deal with it and a simulation study evaluating their performance. 588 Ecography 36:27-46. DOI: 10.1111/j.1600-0587.2012.07348.x

589 Dungey HS. 2001. Pine hybrids: a review of their use performance and genetics. Forest Ecol 590 Manag 148:243-258.

591 Dvorak WS. 2008. Estamos más cerca de entender la ascendencia de las poblaciones de la 592 "variante patula" en la Sierra Madre del Sur, México? Forest Veracruz 10:59-66.

593 Dvorak WS, Jordon AP, Hodge GP, Romero JL. 2000. Assessing evolutionary relationships of 594 pines in the Oocarpae and Australes subsections using RAPD markers. New Forests 20:163-192. 595 Dvorak WS, Kietzka E, Hodge GR, Nel A, Dos Santos GA, Gantz C. 2007. Assessing the 596 potential of Pinus herrerae as a plantation species for the subtropics. Forest Ecol Manag $597 \quad 242: 598-605$.

598 Escobar-Flores JG, Lopez-Sanchez CA, Sandoval S, Marquez-Linares MA, Wehenkel C. 2018. 599 Predicting Pinus monophylla forest cover in the Baja California Desert by remote sensing. PeerJ 600 6:e4603.

601 Falush D, Stephens M, Pritchard JK. 2007. Inference of population structure using multilocus 602 genotype data: dominant markers and null alleles. Mol Ecol 7:574-578.

603 Farjon A, Styles BT (1997) Pinus (Pinaceae). Flora Neotropica Monograph. New York, NY: The 604 New York Botanical Garden.

605 Fawcett T 2006. An introduction to ROC analysis. Pattern Recognition Letters 27(8):861-874.

606 Fogelqvist J, Verkhozina AV, Katyshev AI, Pucholt P, Dixelius C, Rönnberg-Wästljung AC, 607 Berlin S. 2015. Genetic and morphological evidence for introgression between three species of 608 willows. BMC Evol Biol 15:193, doi: 10.1186/s12862-015-0461-7.

609 Futuyma DJ. 1998. Evolutionary Biology. Sunderland, Massachussetts, Sinauer Associates Inc.

610 García-Arévalo A, González-Elizondo MS. 2003. Pináceas de Durango. CONAFOR- Instituto de 611 Ecología, AC. México, D.F. 187 pp.

612 Garrett PW. 1979. Species hybridization in the genus Pinus. USDA Forest Service, Northeast 613 Forest Experiment Station, Station Research Paper 436.

614 Gernandt DS, Aguirre Dugua X, Vázquez-Lobo A, Willyard A, Moreno Letelier A, Pérez de la 615 Rosa JA, Piñero D, Liston A. 2018. Multi-locus phylogenetics, lineage sorting, and reticulation 616 in Pinus subsection Australes. Am J Bot 105:711-725. 
617 Gernandt DS, López GG, Ortiz-García S, Liston A. 2005. Phylogeny and classification of Pinus.

618 Taxon 4:29-42.

619 Gernandt DS, Willyard A, Syring JV, Liston A. 2011. The Conifers (Pinophyta), pp. 1-39 in:

620 Plomion C, Bousquet J, Kole C (eds.) Genetics, Genomics and Breeding of Conifers. Science

621 Publishers, CRC Press.

622 Gómez JM, González-Megías A, Lorite J, Abdelaziz M, Perfectti F. 2015. The silent extinction:

623 climate change and the potential hybridization-mediated extinction of endemic high-mountain 624 plants. Biodivers Conserv 24:1843-1857.

625 Gompert Z, Buerkle CA. 2016. What, if anything, are hybrids: enduring truths and challenges 626 associated with population structure and gene flow. Evol Appl:909-923, doi:10.1111/eva.12380

627 González-Elizondo MS, González-Elizondo M, Sørensen PD. 2012a. Arbutus bicolor (Ericaceae, 628 Arbuteae), una nueva especie de México. Acta Bot Mex 99:55-72.

629 González-Elizondo MS, González-Elizondo M, Zamudio S. 2012b. Delimitación taxonómica de 630 Arbutus mollis y A. occidentalis (Ericaceae). Acta Bot Mex 101:49-81.

631 González-Elizondo MS, González-Elizondo M, Tena-Flores JA, Ruacho-González L, López-

632 Enríquez IL. 2012c. Vegetación de la Sierra Madre Occidental, México: una síntesis. Acta Bot 633 Mex 100:351-403.

634 González-Elizondo MS, González-Elizondo M, González LR, Enríquez IL, Rentería FR, Flores 635 JT. 2013. Ecosystems and diversity of the Sierra Madre Occidental. USDA For Serv Proc 636 RMRS-P-67.

637 Grant PR, Grant BR. 1994. Phenotypic and genetic effects of hybridization in Darwin's finches. 638 Evolution 48:297-316.

639 Guo YP, Saukel J, Mittermayr R, Ehrendorfer F. 2005. AFLP analyses demonstrate genetic 640 divergence, hybridization, and multiple polyploidization in the evolution of Achillea 641 (Asteraceae-Anthemideae). New Phytol 166:273-290.

642 Hammer Ø, Harper DAT, Ryan PD. 2001. PAST-palaeontological statistics, ver. 1.89. 643 Palaeontologia electronica 4(9).

644 Hardy OJ, Charbonnel N, Freville H, Heuertz M. 2003. Microsatellite allele sizes: a simple test 645 to assess their significance on genetic differentiation. Genetics 163:1467-1482.

646 Harrison RG. 1993. Hybrids and hybrid zones: historical perspective, pp 3-12 in: Harrison RG 647 (ed.) Hybrid zones and the evolutionary process. Ithaca, NY: Oxford University Press. 
648 Hernández-León S, Gernandt DS, Pérez de la Rosa JA, Jardón-Barbolla L. 2013. Phylogenetic 649 relationships and species delimitation in Pinus section Trifoliae inferred from plastid DNA. 650 PLoS One 8(7):e70501.

651 Hipp AL. 2018. Pharaoh's Dance: the oak genomic mosaic. PeerJ Preprints 7:e27405v2 652 DOI:10.7287/peerj.preprints.27405v2.

653 Hipp AL, Manos PS, Hahn M, Avishai M, Bodénès C, Cavender-Bares J, Crowl A, Deng M, 654 Denk T, Fitz-Gibbon S, Gailing O, González-Elizondo MS, González-Rodríguez A, Grimm GW, 655 Jiang X-L, Kremer A, Lesur I, McVay JD, Plomion C, Rodríguez-Correa H, Schulze E-D, 656 Simeone MC, Sork VL, Valencia-Avalos S. 2019. Genomic landscape of the global oak 657 phylogeny. New Phytol (2019) DOI: 10.1111/nph.16162.

658 Hongwane P, Mitchell G, Kanzler A, Verryn S, Lopez J, Chirwa P. 2018. Alternative pine 659 hybrids and species to Pinus patula and P. radiata in South Africa and Swaziland. South For 660 80:301-310 DOI: 10.2989/20702620.2017.1393744.

661 Jasso-Martínez JM, Machkour-M'Rabet S, Vila R, Rodríguez-Arnaiz R, Castañeda-Sortibrán 662 AN. 2018. Molecular evidence of hybridization in sympatric populations of the Enantia jethys 663 complex (Lepidoptera: Pieridae). PLoS ONE 13(5):e0197116 DOI: 664 10.1371/journal.pone.0197116.

665 Kaplan Z, Fehrer J. 2007. Molecular evidence for a natural primary triple hybrid in plants 666 revealed from direct sequencing. Ann Bot 99:1213-1222.

667 Kedharnath S. 1984. Forest tree improvement in India. Proc Ind Acad Sci (P1 Sci) 93: 401-412.

668 Koerber GR, Anderson PA, Seekamp JV. 2013. Morphology, physiology and AFLP markers 669 validate that green box is a hybrid of Eucalyptus largiflorens and E. gracilis (Myrtaceae). Aust 670 Syst Bot 26:156-166.

671 Krauss SL. 2000. Accurate gene diversity estimates from amplified fragment length 672 polymorphism (AFLP) markers. Mol Ecol 9:1241-1245.

673 Lanner RM. 1974. A new pine from Baja California and the hybrid origin of Pinus quadrifolia. 674 Southwest Nat 19:75-95.

675 LaRue EA, Grimm D, Thum RA. 2013. Laboratory crosses and genetic analysis of natural 676 populations demonstrate sexual viability of invasive hybrid watermilfoils (Myriophyllum 677 spicatum $\times$ M. sibiricum). Aquat Bot 109:49-53. 
678 Ledig FT. 1998. Genetic variation in Pinus, pp. 251-280 in: Richardson DM (ed.) Ecology and 679 biogeography of Pinus. Cambridge, U. K.: Cambridge University Press.

680 Lexer C, Fay MF, Joseph JA, Nica MS, Heinze B. 2005. Barrier to gene flow between two 681 ecologically divergent Populus species, P. alba (white poplar) and P. tremula (European aspen): 682 the role of ecology and life history in gene introgression. Mol Ecol 14:1045-1057. Linder CR, 683 Risenberg LH. 2004. Reconstructing patterns of reticulate evolution in plants. Am J Bot 684 91(10):1700-1708 DOI:10.3732/ajb.91.10.1700.

685 Linder CR, Taha I, Rieseberg LH, Seiler GJ, Snow AA. 1998. Long-term introgression of crop 686 genes into wild sunflower populations. Theor Appl Genet 96:339-347.

687 Little EL, Righter FI. 1965. Botanical descriptions of forty artificial pine hybrids. US Dept. of 688 Agriculture.

689 Lopez JJ, Abt RC, Dvorak WS, Hodge GR, Phillips R. 2018. Tree breeding model to assess 690 financial performance of pine hybrids and pure species: deterministic and stochastic approaches 691 for South Africa. New Forests 49:123-142.

692 López-Upton J, Fiscal VV, Mata JJ, Herrera CR, Hernández JJV. 2001. Hibridación natural entre 693 Pinus oocarpa y P. pringlei. Acta Bot Mex 57:51-66.

694 Mabaso F, Ham H, Nel A. 2019. Frost tolerance of various Pinus pure species and hybrids. 695 South Forests 81:273-280.

696 Marie AD, Bernatchez L, Garant D. 2011. Empirical assessment of software efficiency and 697 accuracy to detect introgression under variable stocking scenarios in brook charr (Salvelinus 698 fontinalis). Conservation Genetics 12(5): 1215. doi.org/10.1007/s10592-011-0224-y

699 Martínez M. 1948. Los pinos mexicanos. 2nd ed Botas, Universidad Nacional Autónoma de 700 México, México, D.F. 361 pp.

701 McVay JD, Hipp AL, Manos PS. 2017. A genetic legacy of introgression confounds phylogeny 702 and biogeography in oaks. Proceedings of the Royal Society B 284: 20170300.

703 Menon M, Bagley JC, Friedline CJ, Whipple AV, Schoettle AW, Leal-Saenz A, Wehenkel C, 704 Molina-Freaner F, Flores-Renteria L, Gonzalez-Elizondo MS, Sniezko RA, Cushman SA, 705 Waring KM, Eckert AJ. 2018. The role of hybridization during ecological divergence of 706 southwestern white pine (Pinus strobiformis) and limber pine (P. flexilis). Mol Ecol 27:1245707 1260 DOI:10.1111/mec.14505. 
708 Menon M, Landguth E, Leal-Saenz A, Bagley J, Schoettle A, Wehenkel C, Flores-Renteria L,

709 Cushman S, Waring K, Eckert A. 2019. Tracing the footprints of a moving hybrid zone under a 710 demographic history of speciation with gene flow. Evol Appl 2019:1-15 DOI: 711 10.1111/eva.12795.

712 Mo J, Xu J, Cao Y, Yang L, Yin T, Hua H, Zhao H, Guo Z, Yang J, Shi J. 2019. Pinus 713 massoniana introgression hybrids display differential expression of reproductive genes. Forests 714 10(3):230 DOI: 10.3390/f10030230.

715 Mueller UG, Wolfenbarger LL. 1999. AFLP genotyping and fingerprinting. Trends Ecol Evol 716 14(10):389-394.

717 Nei M. 1972. Genetic distance between populations. Am Nat 106:283-292.

718 Nei M. 1978. Estimation of average heterozygosity and genetic distance from a small number of 719 individuals. Genetics 89:583-590.

720 Nielsen EE, Bach LA, Kotlicki P. 2006. HYBRIDLAB (version 1.0): a program for generating 721 simulated hybrids from population samples. Mol Ecol Notes 6(4):971-973.

722 Ortiz-Martínez A, Gernandt D. 2016. Species diversity and plastid DNA haplotype distributions 723 of Pinus subsection Australes (Pinaceae) in Guerrero and Oaxaca. TIP Rev Esp Cienc Quím Biol 724 19(2):92-101.

725 Owens GL, Samuk K. 2019. Adaptive introgression during environmental change can weaken 726 reproductive isolation. bioRxiv 553230 DOI: 10.1101/553230.

727 Paun O, Schönswetter P. 2012. Amplified Fragment Length Polymorphism (AFLP) - an 728 invaluable fingerprinting technique for genomic, transcriptomic and epigenetic studies. Methods 729 Mol Biol 862:75-87 DOI: 10.1007/978-1-61779-609-8_7.

730 Peakall R, Smouse PE. 2012. GenAlEx 6.5: Genetic analysis in Excel. Population genetic 731 software for teaching and research-an update. Bioinformatics 28:2537-2539.

732 Peñaloza-Ramírez JM, González-Rodríguez A, Mendoza-Cuenca L, Caron H, Kremer A, Oyama 733 K. 2010. Interspecific gene flow in a multispecies oak hybrid zone in the Sierra Tarahumara of 734 Mexico. Ann Bot 105:389-399.

735 Pérez de la Rosa JA. 1998. Promoción de una variedad de pino serotino mexicano a nivel de 736 especie. Bol Inst Bot Univ Guad (IBUG) 5:127-135.

737 Pérez de la Rosa JA, Vargas Amado G. 2009. Pinus luzmariae Pérez de la Rosa (PINACEAE) y 738 su situación actual en el Bosque La Primavera, Zapopan, Jalisco. II Foro de Investigación y 
739 Conservación del Bosque La Primavera, 5 y 6 de marzo de 2009, Centro Universitario de

740 Ciencias Biológicas y Agropecuarias de la Universidad de Guadalajara, México.

741 Pérez de la Rosa J, Farjon A. 2013. Pinus luzmariae. The IUCN Red List of Threatened Species

742 2013: e.T42378A2976301 DOI: 10.2305/IUCN.UK.2013-1.RLTS.T42378A2976301

743 Perry JP. 1991. The pines of Mexico and Central America. Portland, OR. Timber Press.

744 Petit RJ, Hampe A. 2006. Some evolutionary consequences of being a tree. Ann Rev Ecol Evol

745 Syst 37:187-214 DOI: 10.1146/annurev.ecolsys.37.091305.110215.

746 Porras-Hurtado L, Ruiz Y, Santos C, Phillips C, Carracedo Á, Lareu M. 2013. An overview of

747 STRUCTURE: applications, parameter settings, and supporting software. Frontiers in Genetics $748 \quad 4: 98$.

749 Price RA, Liston A, Strauss SH. 1998. Phylogeny and systematics of Pinus, pp 49-68 in:

750 Richardson DM (ed.), Ecology and Biogeography of Pinus. Cambridge University Press, 751 Cambridge, UK.

752 Pritchard JK, Stephens M, Donnelly P. 2000. Inference of population structure using multilocus 753 genotype data. Genetics 155:945-959.

754 Quijada A, Liston A, Robinson W, Alvarez-Buylla E. 1997. The ribosomal ITS region as a 755 marker to detect hybridization in pines. Mol Ecol 6:995-996.

756 R Development Core Team. 2018 R: a language and environment for statistical computing. R

757 Foundation for Statistical Computing, Vienna. http://www.R-project.org

758 Rhymer JM, Simberloff D. 1996. Extinction by hybridization and introgression. Ann. Rev Ecol 759 Syst 27:83-109.

760 Rieseberg LH, Carney SE. 1998. Plant hybridization. New Phytol 140:599-624.

761 Rieseberg LH, Ellstrand NC, Arnold M. 1993. What can molecular and morphological markers 762 tell us about plant hybridization? Crc Cr Rev Plant Sci 12:213-241.

763 Sáenz-Romero C, Tapia-Olivares BL. 2003. Pinus oocarpa Isoenzymatic variation along an 764 altitudinal gradient in Michoacán, México. Silvae Genet 52:237-240.

765 Sáenz-Romero C, Guzmán-Reyna RR, Rehfeldt GE. 2006. Altitudinal genetic variation among 766 Pinus oocarpa populations in Michoacán, Mexico: implications for seed zoning, conservation, 767 tree breeding and global warming. Forest Ecol Manag 229:340-350. 
768 SanCristobal M, Chevalet C, Peleman J, Heuven H, Brugmans B, Van Schriek M, Amigues Y. 769 2006. Genetic diversity in European pigs utilizing amplified fragment length polymorphism 770 markers. Anim Genet 37:232-238.

771 Sánchez González A. 2008). Una visión actual de la diversidad y distribución de los pinos de 772 México. Madera y Bosques 14(1):107-120.

773 Savolainen O, Hedrick P. 1995. Heterozygosity and fitness: no association in Scots Pine. 774 Genetics 140:755-766.

775 Savelkoul PHM, Aarts HJM, de Haas J, Dijkshoorn L, Duim B, Otsen M, Rademaker JLW, 776 Schouls L, Lenstra JA. 1999. Amplified-fragment length polymorphism analysis: the state of an 777 art. J. Clin. Microbiol. 37: 3083-3091.

778 Shasany AK, Darokar MP, Dhawan S, Gupta AK, Gupta S, Shukla AK, Khanuja SP. 2005. Use 779 of RAPD and AFLP markers to identify inter-and intraspecific hybrids of Mentha. J Hered 780 96:542-549.

781 Simental-Rodríguez SL, Quiñones-Pérez CZ, Moya D, Hernández-Tecles E, López-Sánchez C 782 A, Wehenkel C. 2014. The Relationship between Species Diversity and Genetic Structure in the 783 Rare Picea chihuahuana Tree Species Community, Mexico. PloS ONE 9(11): e111623 DOI: 784 10.1371/journal.pone.0111623.

785 Smulders MJM, Beringen R, Volosyanchuk R, vanden Broeck AV, Van der Schoot J, Arens P, 786 Vosman B. 2008. Natural hybridisation between Populus nigra L. and P. x canadensis Moench. 787 Hybrid offspring competes for niches along the Rhine river in the Netherlands. Tree Gen Genom 788 4:663-675.

789 Stacy EA, Paritosh B, Johnson MA, Price DK. 2017. Incipient ecological speciation between 790 successional varieties of a dominant tree involves intrinsic postzygotic isolating barriers. Ecol 791 Evol 7:2501-2512 DOI: 10.1002/ece3.2867.

792 Stewart JF, Liu Y, Tauer CG, Nelson CD. 2010. Microsatellite versus AFLP analyses of pre793 management introgression levels in loblolly pine (Pinus taeda L.) and shortleaf pine (P. echinata 794 Mill.). Tree Gen Genom 6(6):853-862 DOI: 10.1007/s11295-010-0296-8.

795 Strauss SH. 1987. Heterozygosity and developmental stability under inbreeding and 796 crossbreeding in Pinus attenuata. Evolution 41:331-339. 
797 Strobl C, Malley JD, Tutz G. 2009. An Introduction to Recursive Partitioning: Rationale, 798 Application and Characteristics of Classification and Regression Trees, Bagging and Random 799 Forests. Psychol Methods 14:323-348 DOI: 10.1037/a0016973

800 Styles BT, Stead JW. 1982. Studies of variation in Central American pines. II. Putative 801 hybridization between Pinus caribaea var. hondurensis and P. oocarpa. FAO.

802 Tatler J, Cassey P, Prowse TA. 2018. High accuracy at low frequency: detailed behavioural 803 classification from accelerometer data. Journal of Experimental Biology 221(23):jeb184085.

804 Thiers B. 2019. Index Herbariorum: A global directory of public herbaria and associated staff. 805 New York Botanical Garden's Virtual Herbarium. <sweetgum.nybg.org/science/ih/> (accessed 806 Oct 21, 2019).

807 Tovar-Sánchez E, Oyama K. 2004. Natural hybridization and hybrid zones between Quercus 808 crassifolia and Quercus crassipes (Fagaceae) in Mexico: morphological and molecular evidence. 809 Am J Bot 91:1352-1363.

810 Ungerer MC, Baird SJ, Pan J, Rieseberg LH. 1998. Rapid hybrid speciation in wild sunflowers. 811 Proceedings of the National Academy of Sciences 95:11757-11762.

812 VÄHÄ JP, Primmer CR. 2006. Efficiency of model-based Bayesian methods for detecting 813 hybrid individuals under different hybridization scenarios and with different numbers of loci. 814 Mol Ecol 15(1):63-72.

815 Vanden Broeck AV, Storme V, Cottrell JE, Boerjan W, Van Bockstaele E, Quataert P, Van 816 Slycken J. 2004. Gene flow between cultivated poplars and native black poplar (Populus nigra 817 L.): a case study along the river Meuse on the Dutch-Belgian border. Forest Ecol Manag $818 \quad 197: 307-310$.

819 Vargas-Mendoza CF, Rodríguez-Banderas A, Ibarra-Sánchez CL, Romero-Salas EA, Medina820 Jaritz NB, Alcalde-Vázquez R. 2011. Phylogenetic Analysis of Mexican Pine Species Based on 821 Three Loci from Different Genomes (Nuclear, Mitochondrial and Chloroplast), pp. 139-154 in: 822 Agboola JI (ed.) Relevant Perspectives in Global Environmental Change. InTech. Austria.

823 Vasilyeva G, Semerikov VL. 2014. Application of amplified fragment length polymorphisms 824 markers to study the hybridization between Pinus sibirica and P. pumila. Annals of Forest 825 Research 57(2): 175-180 DOI: 10.15287/afr.2014.219.

826 Vasilyeva G, Goroshkevich S. 2018. Artificial crosses and hybridization frequency in five-needle 827 pines. Dendrobiology 80:123-130 DOI:10.12657/denbio.080.012. 
828 Vekemans X, Hardy OJ. 2004. New insights from fine-scale spatial genetic structure analyses in 829 plant populations. Mol Ecol 13:921-935.

830 Venables WN, Ripley BD. 1999. Chapter 10: Tree-based methods. In Modern Applied Statistics 831 with S-PLUS. 3rd ed. Eds. J. Chambers, W. Eddy, W. Härdle, S. Sheather, L. Tierney. Statistics 832 and Computing (Springer-Verlag, Press), New York, NY, pp 303-327 DOI: 10.1007/978-1-4757833 3121-7_10.

834 Vos P, Hogers R, Bleeker M, Reijans M, Van de Lee T, Hornes M, Zabeau M. 1995. AFLP: a 835 new technique for DNA fingerprinting. Nucleic Acids Res 23:4407-4414.

836 Vuylsteke M, Mank R, Antonise R, Bastiaans E, Senior ML, Stuber CW, Zabeau M. 1999. Two 837 high-density AFLP® linkage maps of Zea mays L.: analysis of distribution of AFLP markers. 838 Theor Appl Genet 99:921-935.

839 Wehenkel C, Simental-Rodríguez LS, Silva-Flores R, Hernández-Díaz C, López-Sánchez CA, 840 Antúnez P. 2015. Discrimination of 59 seed stands of various Mexican pine species based on 43 841 dendrometric, climatic, edaphic and genetic traits. Forstarchiv 86:194-201.

842 Wendel JF, McD J, Rettig JH. 1991. Molecular evidence for homoploid reticulate evolution 843 among Australian species of Gossypium. Evolution 45(3):694-711.

844 Williams CK, Engelhardt A, Cooper T, Mayer Z, Ziem A, Scrucca L, Kuhn MM. 2018. Package 845 'caret'.

846 Wright JW. 1964. Mejoramiento genético de los árboles forestales. FAO. Roma, pp 173-203.

$847 \mathrm{Xu}$ S, Tauer CG, Nelson CD. 2008. Natural hybridization within seed sources of shortleaf pine 848 (Pinus echinata Mill.) and loblolly pine (Pinus taeda L.). Tree Gen Genom 4:849-858.

849 Zhao W, Meng J, Wang B, Zhang L, Xu Y, Zeng Q-Y, Li Y, Mao J-F, Wang X-R. 2014. Weak 850 crossability barrier but strong juvenile selection supports ecological speciation of the hybrid pine 851 Pinus densata on the Tibetan Plateau. Evolution 68:3120-3133 DOI: 10.1111/evo.12496. 


\section{Table 1 (on next page)}

Locations of the the stands of Pinus herrerae (PH) and Pinus luzmariae (PL) under study

Locations of the the stands of Pinus herrerae (PH) and Pinus luzmariae (PL) under study 


\begin{tabular}{|c|c|c|c|c|c|c|}
\hline $\begin{array}{l}\text { Abbreviated } \\
\text { stand name }\end{array}$ & Property & Seed stand & Municipality & $\begin{array}{l}\text { Latitude } \\
\text { (N) }\end{array}$ & $\begin{array}{c}\text { Longitude } \\
\text { (W) }\end{array}$ & $\begin{array}{c}\text { Elevation } \\
\text { (m) }\end{array}$ \\
\hline \multirow{2}{*}{ PH-R } & Comunidad & \multirow{2}{*}{ Ranchito } & Pueblo & $23^{\circ} 31^{\prime}$ & $105^{\circ} 05^{\prime}$ & \multirow{2}{*}{2,511} \\
\hline & Milpillas & & Nuevo & 46.8” & 11.3' & \\
\hline \multirow{2}{*}{ PH-A } & Comunidad & Manchon del & Pueblo & $23^{\circ} 11^{\prime}$ & $105^{\circ} 02^{\prime}$ & \multirow{2}{*}{2,318} \\
\hline & Lajas & Abies & Nuevo & $15.1^{\prime \prime}$ & $45.5^{\prime}$ & \\
\hline \multirow{2}{*}{$\mathrm{PH}-\mathrm{V}$} & Comunidad & \multirow{2}{*}{ Ventana } & Pueblo & $23^{\circ} 12^{\prime}$ & $105^{\circ} 01^{\prime}$ & \multirow{2}{*}{2,396} \\
\hline & Lajas & & Nuevo & 08.3” & 13.7” & \\
\hline \multirow{2}{*}{ PL-L } & Comunidad & \multirow{2}{*}{ Laguna } & Pueblo & $23^{\circ} 10^{\prime}$ & $105^{\circ} 07^{\prime}$ & \multirow{2}{*}{1,960} \\
\hline & Lajas & & Nuevo & 18.4" & $25.4^{\prime}$ & \\
\hline \multirow{2}{*}{ PL-T } & Comunidad & \multirow{2}{*}{ Tacuache } & Pueblo & $23^{\circ} 10^{\prime}$ & $105^{\circ} 08^{\prime}$ & \multirow{2}{*}{2,140} \\
\hline & Lajas & & Nuevo & 47.8” & 46.0” & \\
\hline
\end{tabular}




\section{Table 2 (on next page)}

Cone and needle traits used in the study.

Cone and needle traits of pure Pinus herrerae and Pinus luzmariae used in the study, min = minimum, $\max =$ maximum, $\mathrm{SD}=$ Standard deviation . 


\begin{tabular}{|l|c|c|c|c|c|c|}
\hline \multirow{2}{*}{\multicolumn{1}{c|}{ Morphological traits }} & \multicolumn{3}{c|}{ Pinus herrerae } & \multicolumn{3}{c|}{ Pinus luzmaria } \\
\cline { 2 - 7 } & $\begin{array}{c}\text { ma } \\
\text { X }\end{array}$ & mean & min & max & mean & min \\
\hline Cone shape (ovoid (1) vs. widely ovoid (2)) & 1 & 1 & 1 & 2 & 2 & 2 \\
\hline Cone width (cm) & 3.5 & 3.1 & 2.8 & 5.2 & 4.8 & 4.1 \\
\hline Cone scale position (ascendant (1) vs. divergent (3)) & 1 & 1 & 1 & 2 & 2 & 2 \\
\hline Cone scale length (cm) & 1.5 & 1.3 & 1.1 & 1.9 & 1.7 & 1.7 \\
\hline Cone scale width (cm) & 0.8 & 0.7 & 0.6 & 1.1 & 0.9 & 0.8 \\
\hline Apophysis width (mm) & 5 & 4.6 & 4 & 8 & 6.8 & 6 \\
\hline Keel (inconspicuos (0) vs. prominent (1)) & 1 & 0.4 & 0 & 0 & 0 & 0 \\
\hline Leaf sheath length (cm) & 1.3 & 1.1 & 0.9 & 2.0 & 1.8 & 1.5 \\
\hline Leaf sheath diameter (mm) & 1.4 & 1.2 & 1.0 & 1.9 & 1.8 & 1.7 \\
\hline Needle number & 3.0 & 3.0 & 3.0 & 3.5 & 3.2 & 3.0 \\
\hline Needle length (cm) & 15.9 & 13.4 & 11.3 & 28.8 & 24.4 & 21.5 \\
\hline Needle width (mm) & 1.0 & 0.8 & 0.7 & 1.3 & 1.2 & 1.1 \\
\hline Needle thickness (mm) & 0.3 & 0.2 & 0.1 & 0.6 & 0.5 & 0.4 \\
\hline Stomata rows (dorsal face) & 9.0 & 7.1 & 5.3 & 10.0 & 9.7 & 9.0 \\
\hline Stomata rows (ventral faces) & 3.3 & 3.1 & 3.0 & 6.0 & 5.0 & 4.0 \\
\hline
\end{tabular}




\section{Table 3(on next page)}

Detection of hybrid trees by analysis of 348 AFLP markers

Detection of hybrid trees by analysis of 348 AFLP markers with the software programs STRUCTURE version 2.1 and NewHybrids version 1.1, PH = Pinus herrerae, $\mathrm{PL}=$ Pinus luzmariae seed stands, $\mathrm{PH}-\mathrm{A}=$ Manchon del Abies, $\mathrm{PH}-\mathrm{R}=$ Ranchito, $\mathrm{PH}-\mathrm{V}=$ Ventana, $\mathrm{PL}-$ $\mathrm{L}=$ Laguna and PL-T=Tacuache. 


\begin{tabular}{ccccccc}
\hline & \multicolumn{5}{c}{ STRUCTURE 2.1 } & \multicolumn{4}{c}{ NewHybrids 1.1 } \\
\hline $\begin{array}{c}\text { Seed } \\
\text { stand }\end{array}$ & $\begin{array}{c}\text { Sample } \\
\text { number }\end{array}$ & $\begin{array}{c}\text { Hybrid } \\
\text { number }\end{array}$ & $\begin{array}{c}\text { F }_{\boldsymbol{l}} \text { hybrid } \\
\text { number }\end{array}$ & $\begin{array}{c}\text { Hybrid } \\
\text { number }\end{array}$ & $\begin{array}{c}\text { F }_{\boldsymbol{l}} \text { hybrid } \\
\text { number }\end{array}$ & $\begin{array}{c}\text { Backcrossing } \\
\text { number }\end{array}$ \\
\hline PH-A & 35 & 35 & 2 & 9 & 0 & 0 \\
PH-R & 33 & 6 & 0 & 0 & 0 & 0 \\
PH-V & 35 & 14 & 0 & 2 & 0 & 1 \\
PL-L & 35 & 30 & 1 & 33 & 0 & 14 \\
PL-T & 33 & 7 & 0 & 21 & 0 & 4 \\
total & & 92 & 3 & 65 & 0 & 16 \\
\hline
\end{tabular}

1 


\section{Table 4 (on next page)}

Accuracy of assignment of Pinus herrerae, Pinus luzmariae and their hybrids using STRUCTURE 2.1 and NewHybrids 1.1.

Accuracy of assignment of Pinus herrerae (PH), Pinus luzmariae (PL) and their hybrids using STRUCTURE 2.1 (STR, Pritchard et al., 2000; Falush et al., 2007) and NewHybrids 1.1 (NH, Anderson \& Thompson, 2002) using a subset of 11 diagnostic AFLP loci and all 348 polymorphic AFLP loci found in the study. Hybrid classes are as follows: $1^{\text {st }}$ gen $-F_{1}, 2^{\text {nd }}$ gen $F_{2}$ and $F_{1}$ backcrosses, and $3^{\text {rd }}$ gen $-F_{2}$ backcrosses and $F_{1}$ double backcrosses (Cullingham et al., 2011) 


\begin{tabular}{|c|c|c|c|c|}
\hline \multirow{2}{*}{2} & \multicolumn{2}{|c|}{ 11 AFLP loci } & \multicolumn{2}{c|}{ 348 AFLP loci } \\
\cline { 2 - 5 } & STR & NH & STR & NH \\
\hline $\mathbf{1}^{\text {st }}$ gen & 1 & 1 & 1 & 1 \\
\hline $\mathbf{2}^{\text {nd }}$ gen & 1 & 0.99 & 1 & 0.99 \\
\hline $\mathbf{3}^{\text {rd }}$ gen & 0.59 & 0.49 & 0.50 & 1.00 \\
\hline Hybrid Avg. & $\mathbf{0 . 8 6}$ & $\mathbf{0 . 8 3}$ & $\mathbf{0 . 8 3}$ & $\mathbf{1 . 0 0}$ \\
\hline $\mathbf{P H}$ & 0.13 & 0.88 & 0.80 & 0.88 \\
\hline $\mathbf{P L}$ & 0.13 & 0.88 & 0.78 & 0.95 \\
\hline
\end{tabular}




\section{Table 5 (on next page)}

Detection of hybrid trees (Pinus herreae x Pinus luzmariae) analysis of seven cone and eight needle traits using Random Forest classification.

Detection of hybrid trees (Pinus herreae $x$ Pinus luzmariae) by analysis of seven cone and eight needle traits using Random Forest classification. $\mathrm{PH}=$ Pinus herrerae, $\mathrm{PL}=$ Pinus luzmariae seed stands, $\mathrm{PH}-\mathrm{A}=$ Manchon del Abies, PH-R=Ranchito, PH-V=Ventana, PL$\mathrm{L}=$ Laguna and PL-T=Tacuache. 


\begin{tabular}{ccccc}
\hline & \multicolumn{2}{c}{ Cone traits } & \multicolumn{2}{c}{ Needle traits } \\
\hline Seed stand & $\begin{array}{c}\text { Sample } \\
\text { number }\end{array}$ & $\begin{array}{c}\text { Hybrid } \\
\text { number }\end{array}$ & $\begin{array}{c}\text { Sample } \\
\text { number }\end{array}$ & $\begin{array}{c}\text { Hybrid } \\
\text { number }\end{array}$ \\
\hline PH-A & 35 & $3(7)$ & 34 & $0(2)$ \\
PH-V & 34 & $0(10)$ & 31 & $2(3)$ \\
PL-L & 31 & $1(3)$ & 13 & $0(4)$ \\
PL-T & 31 & $2(9)$ & 11 & $2(3)$ \\
total & 131 & $6(29)$ & 89 & $4(12)$ \\
\hline
\end{tabular}

1 Note: number in brackets = hybrid number at four of seven cone traits detected and at four of eight needle traits 2 detected 


\section{Figure 1}

Locations of the Pinus herrerae (Pinus teocote var. herrerae) (yellow circles) and Pinus luzmariae stands (red triangles) in the State of Durango, Northwest Mexico.

Locations of the Pinus herrerae (Pinus teocote var. herrerae) ( yellow circles) and Pinus luzmariae stands (red triangles) in the State of Durango, Northwest Mexico. The P. herrerae seed stands were 1) Ranchito (PH-R), Manchon del Abies (PH-A) and Ventana (PH-V). The $P$. luzmariae stands were Laguna (PL-L) and Tacuache (PL-T). 


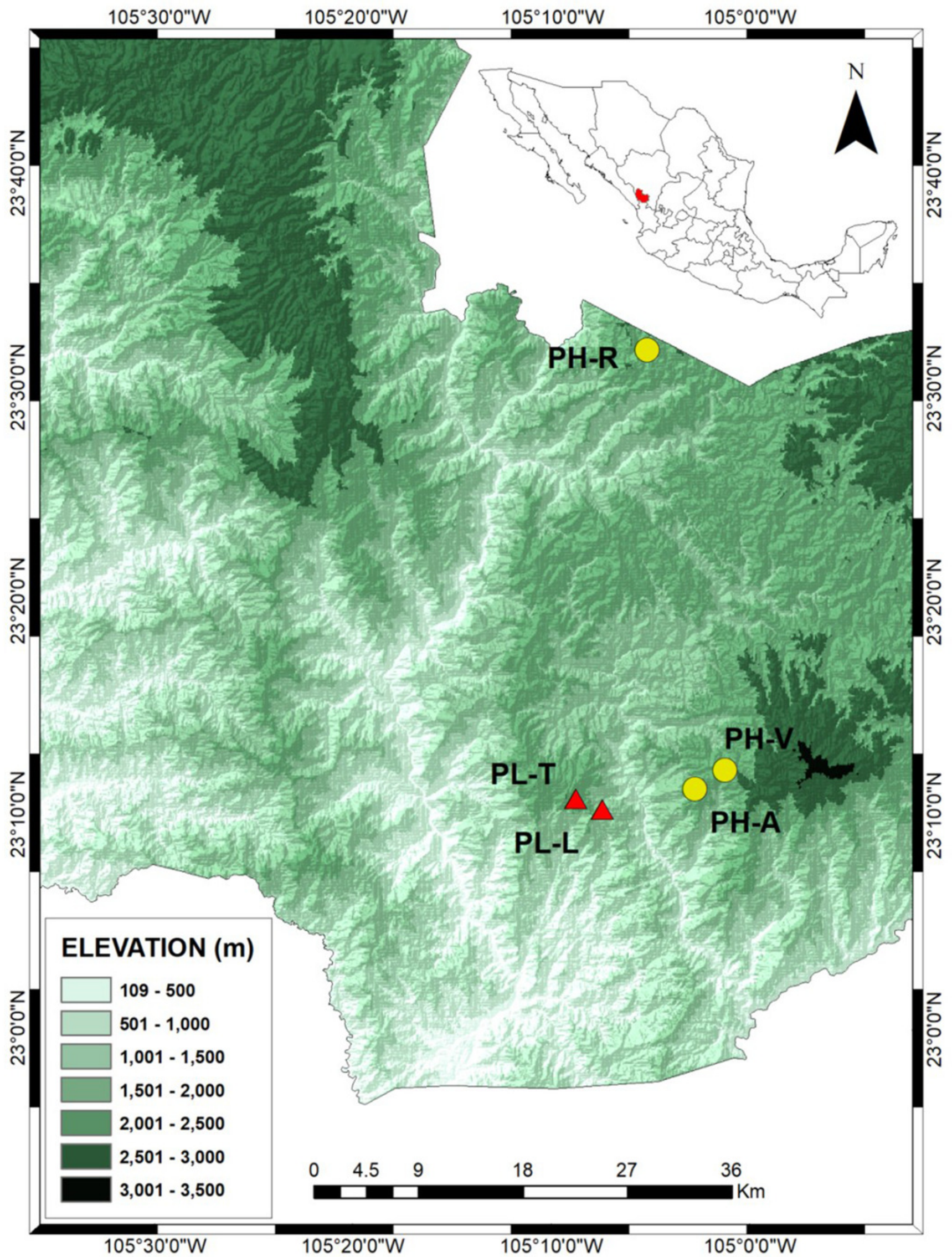




\section{Figure 2}

Identification of two populations ( $\mathrm{K}=2)$ based on 348 AFLP from three Pinus herrerae seed stands (PH) (Pop $1=$ blue) and two Pinus luzmariae seed stands (PL) (Pop $2=$ orange) using STRUCTURE.

Identification of two populations ( $K=2$ ) based on AFLP data from three Pinus herrerae seed stands (PH) (Pop $1=$ blue) and two Pinus luzmariae seed stands (PL) (Pop $2=$ red) (171 individuals in total), with Structure, version 2.1 software. PH-A with 35 hybrids, PH-R with six hybrids, PH-V with 14 hybrids, PL-L with 30 hybrids and PL-T with seven hybrids; PH$\mathrm{A}=$ Manchon del Abies, $\mathrm{PH}-\mathrm{R}=$ Ranchito, $\mathrm{PH}-\mathrm{V}=\mathrm{Ventana}, \mathrm{PL}-\mathrm{L}=\mathrm{L}$ aguna and $\mathrm{PL}-\mathrm{T}=$ Tacuache 


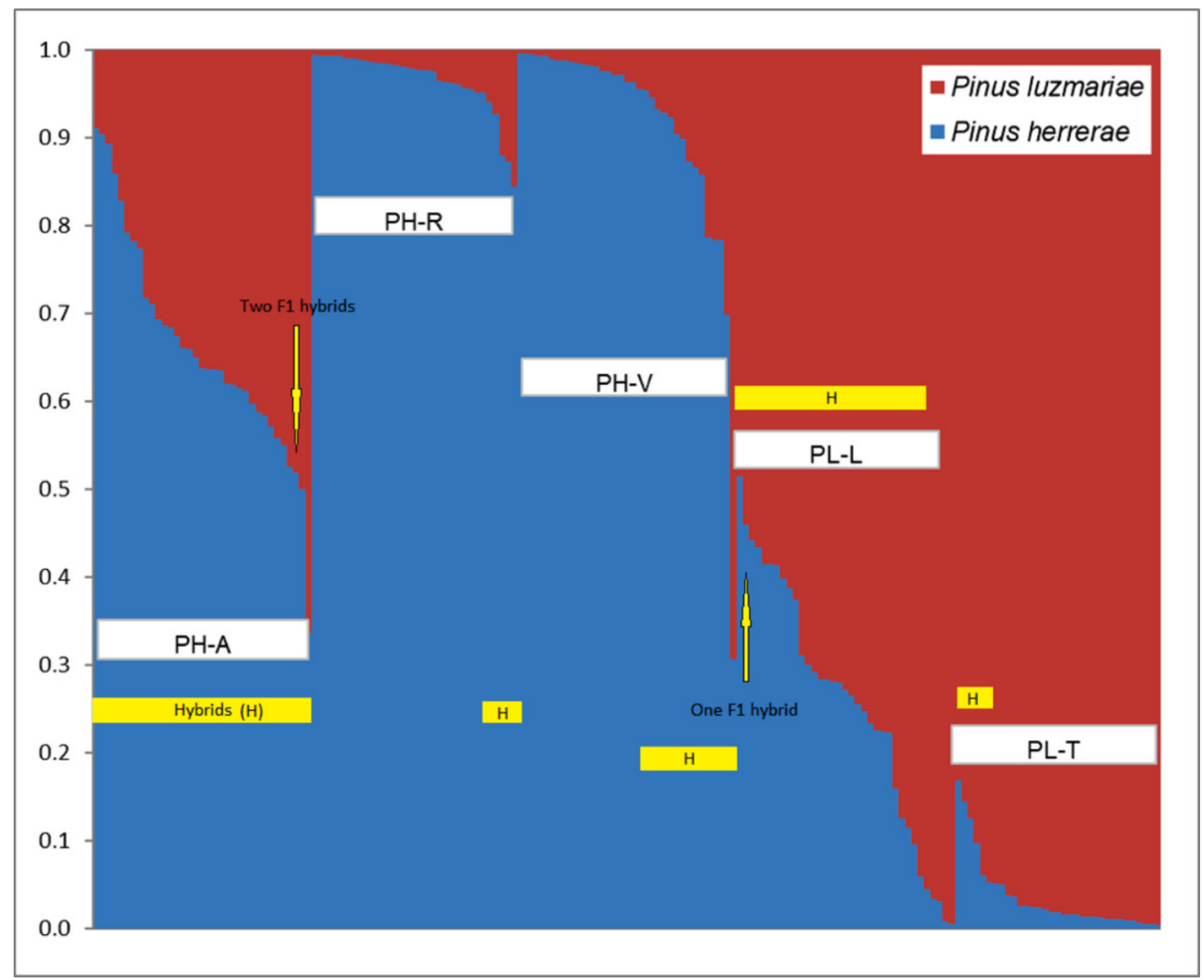




\section{Figure 3}

Images from a typical Pinus luzmariae (A) and a Pinus luzmariae hybrid (B).

Images from a typical Pinus luzmariae (Bolaños, Jalisco, 2013) (A) and a Pinus luzmariae hybrid (seed stand "Laguna" (PL-L), tree 102, 26 m stem height) (B).

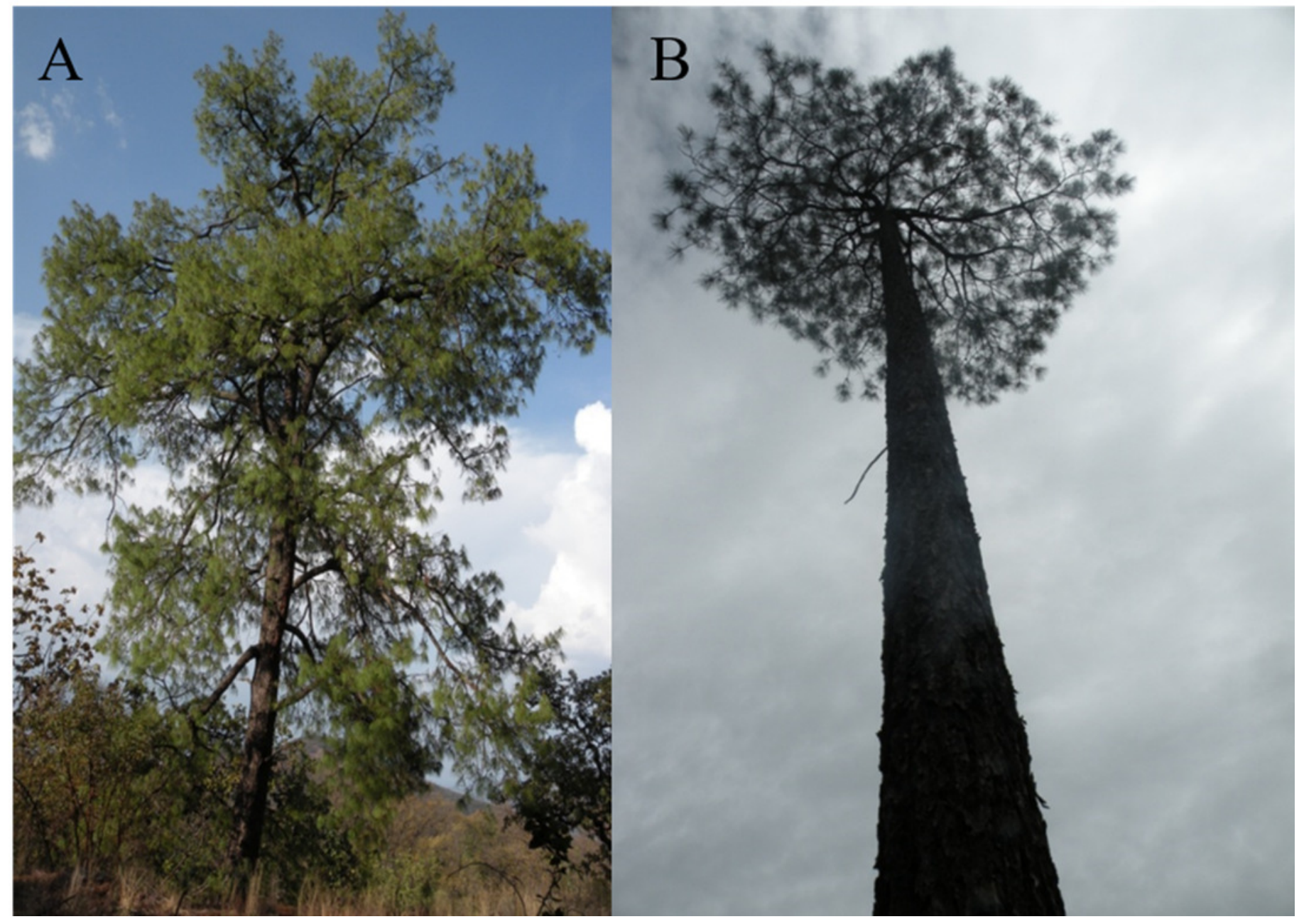


Figure 4

Typical branches, needles and cones of Pinus herrerae and Pinus luzmariae and variation of $P$. luzmariae cones.

Typical branches, needles and cones of Pinus herrerae (A) and Pinus luzmariae (B) and variation of $P$. luzmariae cones: typical (C), different hybrid forms (D-G).

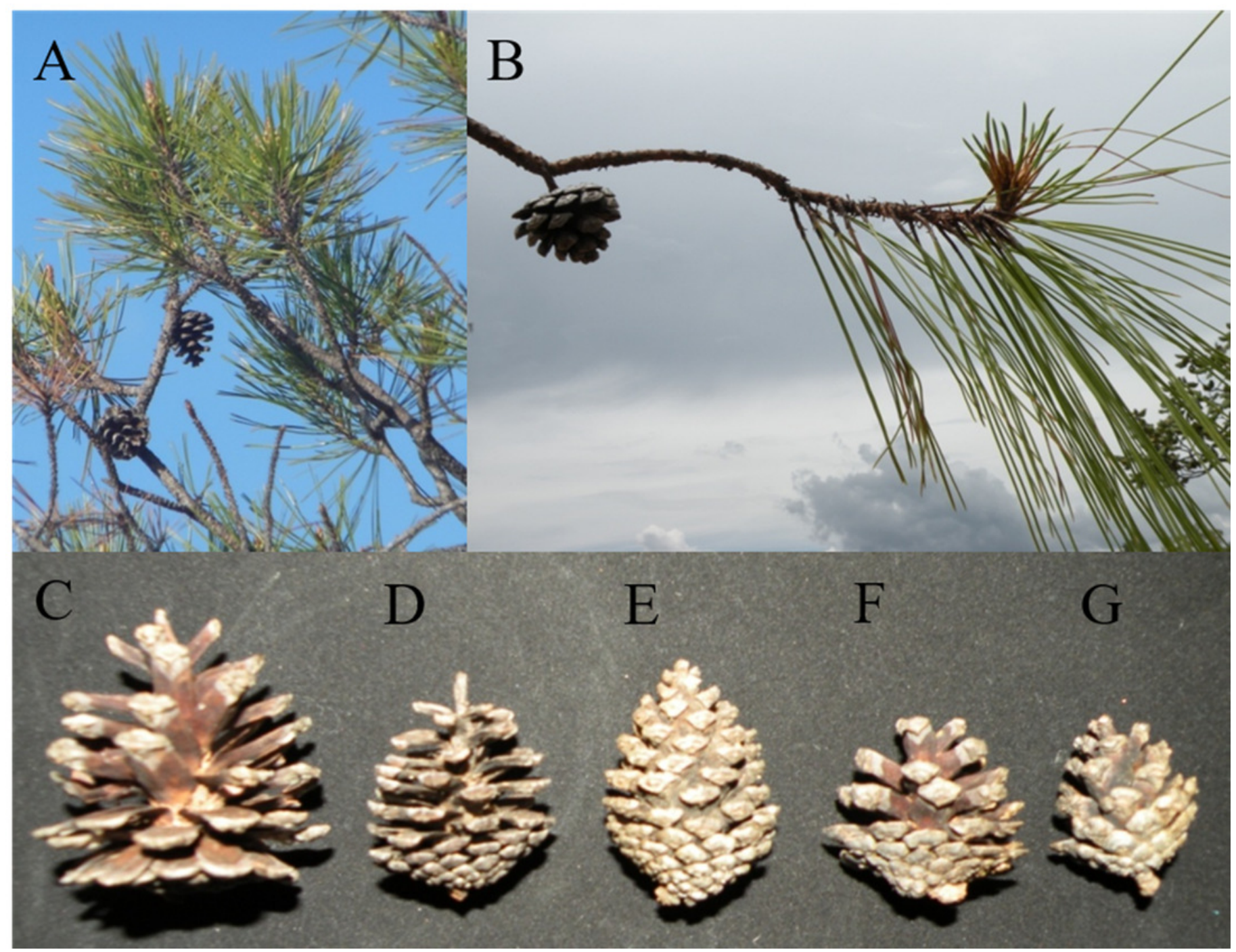




\section{Figure 5}

Posterior probability $(P)$ of being Pinus herrerae and Pinus luzmariae using Random Forest classification.

Posterior probability $(P)$ of being Pinus herrerae $(\mathrm{PH})$ and Pinus luzmariae $(\mathrm{PL})$ that a tree belongs to a particular class (PH or PL) using a Random Forest classification and A) using seven cone traits, B) using eight needle traits; True Skill Statistic (Allouche, Tsoar \& Kadmon, $2006)=+1$. If the $P$ of $\mathrm{PH}$ (or $\mathrm{PL}$ ) affiliation of a possible $\mathrm{PH}$ (or $\mathrm{PL}$ ) tree was less than 0.95 (red lines), then, that tree was considered as a putative PH (or PL) hybrid.

A

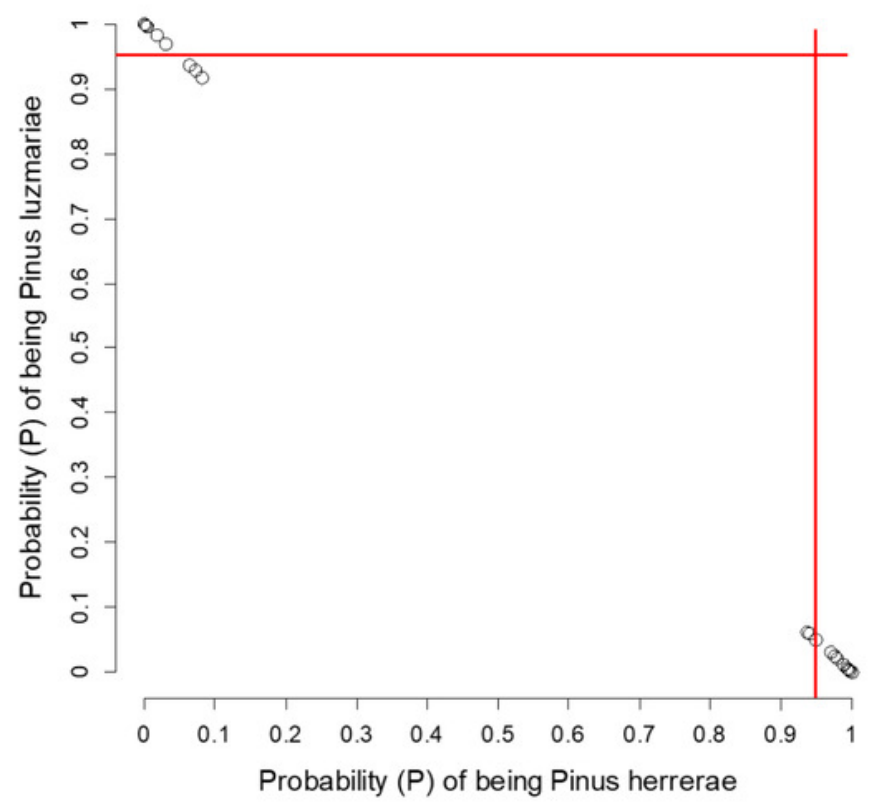

B

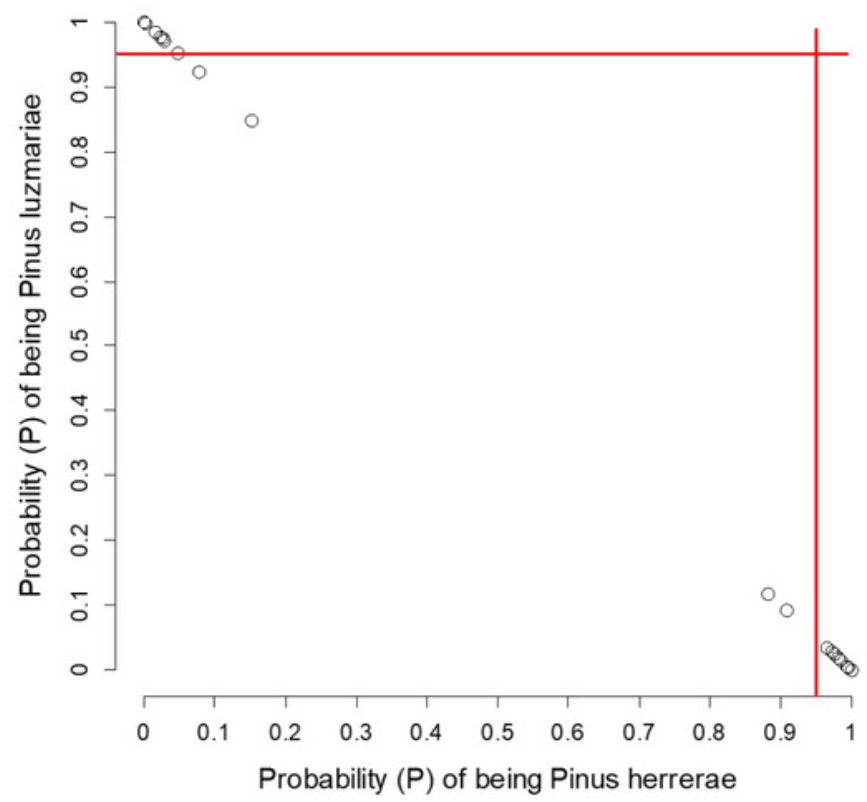




\section{Figure 6}

Clues of possible hybrid vigour in Pinus luzmariae

Clues of possible hybrid vigour in Pinus luzmariae: A) Histogram (tree number) of tree heights $(m)$, red line $=$ normal distribution (probability) of all (69) pure $P$. luzmariae trees and putative hybrids under study, green line $=$ logarithm normal distribution of all pure $P$. luzmariae trees and putative hybrids under study, blue bold line $=$ normal distribution of the pure $P$. luzmariae trees under study, B) normal Q-Q-plot of all (69) pure $P$. luzmariae trees and putative hybrids under study.
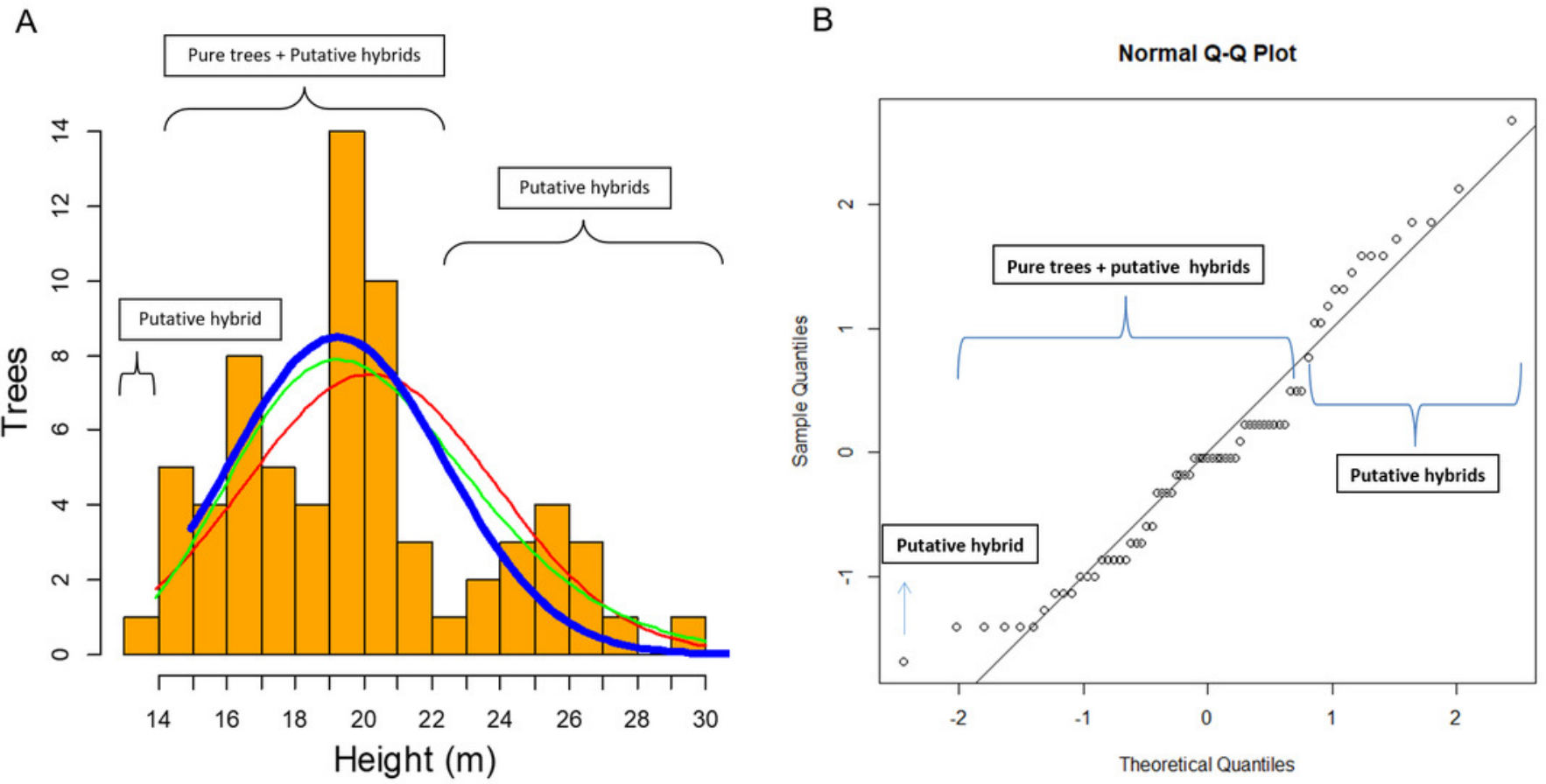